\title{
Psychological Perspectives on Interrogation
}

\author{
Aldert Vrij \\ Christian A. Meissner \\ Ronald P. Fisher \\ Saul M. Kassin \\ Andy Morgan III \\ Steven M. Kleinman
}

Author Note

Aldert Vrij, Department of Psychology, University of Portsmouth; Christian

Meissner, Department of Psychology, Iowa State University; Saul Kassin,

Department of Psychology, John Jay College of Criminal Justice; Ronald Fisher, Department of Psychology, Florida International University; Andy Morgan, Henry

Lee College of Criminal Justice, University of New Haven; Steven Kleinman,

Operational Sciences International.

Correspondence concerning this article should be addressed to Aldert Vrij,

Department of Psychology, University of Portsmouth, King Henry Building, King

Henry 1 Street, PO1 2DY, Hants, United Kingdom. Email aldert.vrij@port.ac.uk 


\begin{abstract}
Proponents of 'enhanced interrogation techniques' in the United States have claimed that such methods are necessary for obtaining information from uncooperative terrorism subjects. In the present article, we offer an informed, academic perspective on such claims. Psychological theory and research shows that harsh interrogation methods are ineffective. First, they are likely to increase resistance by the subject rather than facilitate cooperation. Second, the threatening and adversarial nature of harsh interrogation is often inimical to the goal of facilitating the retrieval of information from memory, and therefore reduces the likelihood that a subject will provide reports that are extensive, detailed, and accurate. Third, harsh interrogation methods make lie detection difficult. Analyzing speech content and eliciting verifiable details are the most reliable cues to assessing credibility; however, to elicit such cues subjects must be encouraged to provide extensive narratives, something that does not occur in harsh interrogations. Evidence is accumulating for the effectiveness of rapport-based, information-gathering approaches as an alternative to harsh interrogations. Such approaches promote cooperation, enhance recall of relevant and reliable information, and facilitate assessments of credibility. Given the available evidence that torture is ineffective, why might some laypersons, policy makers, and interrogation personnel support the use of torture? We conclude our review by offering a psychological perspective on this important question.
\end{abstract}




\section{Psychological Perspectives on Interrogation}

Simulated drowning (waterboarding) leading to vomiting, convulsions, and unconsciousness; debilitating stress positions and prolonged standing for 72 hours; physical abuse, mock executions, and threats to one's family; sleep deprivation, physical isolation, constant noise, and uncomfortably cold temperatures for 180 hours. In 2014, the U.S. Senate Select Committee on Intelligence report on the CIA's detention and interrogation program brought to light details of such detainee abuse (see http://edition.cnn.com/interactive/2014/12/politics/torture-report/). At the same time, the report also confirmed what scholars have long understood (Peters, 1996; Rejali, 2009): torture - the application of coercive physical, psychological, and emotional pressures - typically produces unreliable information.

The CIA's program and its treatment of detainees is far from unique or unprecedented. Civilizations, since at least the ancient Greeks and Romans, have instituted the use of torture on prisoners. While some have reserved its use for those deemed to have no rights (such as slaves), other societies considered these techniques appropriate for securing confessions from citizens and, hence, the administration of justice (Peters, 1996). In times of war or insurgencies, governments have commonly employed torture for no other purpose than to break the will of a detainee (i.e., to apply sufficient force to compel a detainee to comply with any and all demands of the interrogator, to include offering false confessions and/or producing propaganda). In such instances, the production of information of investigative or intelligence value is of little interest (Fein, 1994).

In fact, the use of torture in interrogation and detention settings remains prevalent around the world. In 2014, Amnesty International received reports of the use of torture and ill-treatment by officials in more than 140 countries. Why do 
countries turn to the use of such methods? Rejali (2009) addresses this in his comprehensive text, Democracy and Torture, by pointing to three objectives that appear to underlie the use of torture: (i) to intimidate, (ii) to coerce false confessions for propaganda reasons, and (iii) to gather intelligence information in support of national security.

Prominent historical examples are available of the use of torture for intimidation and the coercion of false confessions. During the Cold War, communist regimes employed various forms of torture to threaten and control prisoners, and to elicit false confessions and statements used for propaganda. For example, the North Koreans and Chinese subjected foreign prisoners to stress positions and prolonged interrogations, forced them to defecate in public, isolated them from all human contact, deprived them of sleep, and offered continual threats of death or bodily harm (Carlson, 2002; Farber, Harlow, \& West, 1957). Such tactics of "touch-less torture" led to "confessions" of a "plot to bomb civilian targets" from thirty-six U.S. airmen all of which were false (Margulies, 2006).

Proponents of torture in the U.S., however, have pointed to Rejali's (2009) third purpose for its use in the "War on Terror" - namely, to gather reliable human intelligence. Former CIA Deputy Director of Operations, Jose Rodriguez (2012) has repeatedly defended his agency's use of such methods, labeled 'enhanced interrogation techniques,' as necessary for obtaining information from uncooperative terrorists. Former U.S. Vice President Dick Cheney and former CIA Director Michael Hayden have similarly offered unapologetic support for the purported effectiveness of such tactics in generating intelligence that ultimately led to the assassination of Osama bin Laden. Most recently, U.S. President Donald Trump, campaigned on the 
promise of returning to the use of enhanced interrogation techniques and other forms of coercion because "it works".

One of the psychologists who facilitated and developed the enhanced interrogation program for the CIA, James Mitchell, has publicly defended the efficacy of these approaches (Mitchell \& Harlow, 2016). In constructing a "psychologically based interrogation program" designed specifically to "condition” Abu Zubaydah (one of the first individuals to be interrogated at a CIA-run black site), Mitchell reports that he "knew it would have to be based on...Pavlovian classical conditioning”. Ironically, he notes that earlier in his career as a behavioral psychologist he had employed Pavlovian conditioning to help his clients "overcome fear and anxiety." Later, as part of the CIA's interrogation program, Mitchell sought to leverage that same method of conditioning to induce fear and anxiety (Mitchell \& Harlow, 2016, pp. 45-46).

Mitchell also emphasizes that both he and his colleague, fellow psychologist Bruce Jessen, were able to accurately assess the counter-interrogation techniques being used by Abu Zubaydah (and others) by identifying his "poker tells, or body language that would tip us off to when he was telling the truth and when he was being deceitful" (Mitchell \& Harlow, 2016, p. 58). As discussed below, such a claim - the ability to meaningfully assess credibility through the observation of nonverbal indicators - runs contrary to well-established research findings that nonverbal indicators of deception are faint and unreliable (DePaulo et al., 2003; Vrij, 2008).

This, of course, is not the only time in U.S. history that officials have debated or resorted to the use of torture to gain purportedly reliable information or confessions. In the early twentieth century, police in the U.S. employed physically and psychologically coercive interrogation methods (referred to as the "third degree") 
that included prolonged confinement and isolation; explicit threats of harm or punishment; deprivations of sleep, food, and other needs; extreme sensory discomfort; and assorted forms of physical violence. As a result of several Supreme Court rulings (most notably Brown v. Mississippi, 1936) in which confessions extracted by physical coercion were ruled inadmissible, U.S. interrogation practices have evolved to the use of more psychologically manipulative, accusatorial approaches that rely instead partly upon trickery and deception (for an historical overview, see Leo, 2008). As described in this review, the reliability of such methods has similarly been questioned, as these approaches have been shown to increase the likelihood of false confessions when applied against the innocent (Kassin, 1997; Kassin et al., 2010; Meissner et al., 2014; Meissner et al., 2015).

The use of torture by U.S. law enforcement and military personnel represents, according to Rejali (2009), "a family of tortures that descended from old West European military and police punishments...to pre-World War II practices of French colonialism...to native American policing practices from the nineteenth century" and ultimately to Abu Ghraib (p. 258). Bell (2008) has proposed a continuum of coercive interrogation practices ranging from classic torture (involving the infliction of severe pain or suffering to including electric shock, direct physical abuse, and prolonged deprivation of food, sleep, or sensation), to cruel, inhuman, and degrading treatment (involving the infliction of moderate physical abuse that may not cause lasting damage), to accusatorial or psychologically coercive methods (involving the manipulation of culpability and perceived consequences associated with confession). It should be noted, however, that any attempt to differentiate "severe" pain from other forms (e.g., arising from cruel acts) is, as Mark Moyer emphasizes in his book on U.S. 
intelligence operations during the Vietnam War, "an exceptionally complicated and imprecise business" (Moyar, 1997, p. 90).

In the present article, we offer an informed, academic perspective on claims regarding the effectiveness of these interrogation tactics for eliciting reliable information. The problem one faces in addressing this question, of course, is that no direct experimental research is available to establish the scientific effectiveness of 'enhanced interrogation techniques' - in fact, such research would violate all principles of research ethics involving human subjects. However, we can extrapolate from observations available within the historical record, from interviews with experienced interrogators and detainees subjected to such methods, from other forms of social influence that we study within the laboratory in an ethical manner, and from the observed effects of laboratory studies involving high arousal.

Sovereign states commonly pursue information via interrogations to support national security interests within two primary domains: law enforcement and intelligence. While it is important to acknowledge that differences exist between interrogations conducted as part of a criminal investigation and those in support of intelligence gathering, such differences arguably have only a modest impact on the nature of the interrogator-subject interaction (see Evans, Meissner, Brandon, Russano, \& Kleinman, 2010). One primary difference between interrogations conducted by law enforcement officials and those carried out by intelligence personnel is that a confession and related information about the past has far greater value in the former, whereas information about the past, present, and future (with information about present and future activities often referred to as "actionable intelligence") can each be of substantial value in the latter, with a confession of only marginal value depending on the situation (Borum et al., 2009). Further, in the criminal setting a subject has, 
depending upon jurisdiction, specific legal safeguards designed to protect them from being compelled to provide statements against their interests, including access to counsel and the right to remain silence. In contrast, subjects interrogated in an intelligence context, particularly as part of a larger international conflict, are generally protected by the provisions of the Geneva Conventions (known widely as Common Article 3) designed to guarantee humane treatment while in enemy hands (see, for example, U.S. Department of Defense, 2011).

These distinctions notwithstanding, the challenges of obtaining cooperation, eliciting information, and assessing credibility - and the relevant interrogation techniques or approaches used to facilitate these actions - are largely identical across criminal and intelligence contexts. Therein, we frame our discussion of interrogation within a criminal or intelligence context using a definition offered previously by Evans et al. (2010, p. 219): the systematic questioning of an individual perceived by investigators as non-cooperative, within a custodial setting, for the purpose of obtaining reliable information in response to specific requirements. To achieve this goal of obtaining reliable information, an interrogation can be divided into three strategic objectives that constitutes its ultimate effectiveness. First, a subject may be reluctant to talk, and the interrogator therefore needs to employ techniques that successfully overcome this resistance to promote cooperation and engagement with the interrogator. Second, the information that a subject possesses is derived from his/her memory, a reality that mandates a tactical objective of only employing techniques that facilitate access to those memories and promote the complete and accurate recall of information retrieved. In the very least, interrogators must be vigilant to avoid conventional and/or coercive methods that have the demonstrated effect of corrupting or diminishing accurate recall. Third, a subject may deliberately 
conceal or fabricate information. Relying on false information can have far reaching consequences, and the interrogator therefore needs to accurately assess the likelihood that the information provided by the subject is truthful.

The remainder of this article addresses the science underlying these three interrogative objectives, with a discussion of the likely influence of torture and accusatorial tactics on each. Within each objective, we also address recent research that has developed a scientific understanding of interrogative approaches that are both ethical and effective. We conclude that the extant literature - which utilizes a variety of methodological approaches ranging from systematic interviews and surveys, to observation and assessment of real-world interrogations, to the development of laboratory paradigms and the conduct of field studies that evaluate the effectiveness of interrogative approaches - substantiates the claim that harsh interrogation methods (including both physical and psychological coercion) are ineffective, particularly when compared with alternative, evidence-based approaches that promote cooperation, enhance recall of relevant and reliable information, and facilitate assessments of credibility. Given the available evidence that both torture and other psychologically manipulative tactics are ineffective, why might laypersons, policy makers, and interrogation personnel support their continued use? We conclude our review by offering a psychological perspective on this important question.

\section{Overcoming Resistance and Achieving Cooperation}

How and why might an interviewee resist an interrogator's request for information? In one of the most informative studies to-date on this issue, Alison et al. (2014a) analyzed 181 interrogations of terrorist suspects in the UK. The researchers identified five counter-interrogation strategies that were frequently employed by these suspects: passive resistance (refusing to look at the interrogator or maintaining 
silence), passive verbal resistance (claiming a lack of memory or offering only monosyllabic responses), direct verbal resistance (offering a scripted response of well-known information, discussing unrelated topics), retraction of prior statements, and direct refusal to engage (no comment or engagement of rights). Terrorist 'training manuals' such as Al Qaeda's Seventeenth Rule or the Provisional Irish Republic Army's Green Book actually suggest the use of such counter-interrogation strategies in preparing individuals for the likelihood of interrogation (including the possibility of torture). Alison et al.'s analysis of the variation in counter-interrogation tactics across such terrorist groups confirmed that the strategies used by terrorism subjects aligned with the specific tactics advocated by the relevant organization's manual.

In an interrogation, subjects are also likely to engage in a cost-benefit analysis, weighing the cost of remaining silent (possibly leading to physical or psychological harm) with the benefit of not providing useful information to the interrogator (saving his/herself and his/her comrades). The use of verbal resistance approaches, as described above, represent a common method for subjects to try to strategically manage the provision of information (Granhag \& Hartwig, 2008): to offer the appearance of providing information to the interrogator, but to leak only that which is false or not particularly useful, and to withhold key details. For instance, a respondent might provide information that an investigator already knows (a strategy that has been used by prisoners of war; cf. Granhag, Oleszkiewicz, Strömwall, \& Kleinman, 2015), provide vague information that cannot be used by the interrogator (cf. Goldsmith, Koriat, \& Weinberg-Eliezer, 2002), or provide information that cannot be verified (Nahari, Vrij \& Fisher, 2014). These strategies have the potential to backfire, though, in that respondents may offer information that they believe the interrogator already knows but which, in fact, is actually of use to an investigation (Granhag, et al, 2015). 
The response of an individual undergoing questioning can also range from complete cooperation to outright defiance. Furthermore, the extensiveness of a response can be directly tied to a specific topic - that is, an individual may offer their full cooperation on one topic (e.g., the involvement of others in an event) while remaining concretely resistant in another (e.g., their personal involvement in an event). While there is a lack of data providing objective estimates of cooperation or resistance across both criminal and intelligence interrogation contexts, operational experience and the limited data available suggest that the prevailing myth of a defiant and completely resistant subject (as depicted in television shows such as ' 24 ') is likely the exception rather than the rule. For example, the U.S. Army Field Manual (FM 2-22.3, 2006) notes that the direct questioning of subjects (which involves directly asking individuals about both pertinent and non-pertinent issues relevant to their detention) led to cooperation and successful elicitation of information $90 \%$ of the time in World War II operations and $95 \%$ of the time in both Vietnam and Middle East operations such as Desert Storm (Kuwait and Iraq, 1991).

Nevertheless, it should also be noted that success of any elicitation tactic is highly dependent upon the level of cooperation obtained. A prime example of this is the Cognitive Interview (Fisher \& Geiselman, 1992; described in more detail below). Although decades of empirical research and field validation have demonstrated its utility in enhancing recall (see Memon, Meissner, \& Fraser, 2010), its application and efficacy are contingent upon the cooperation of the subject being questioned.

Given the need to obtain cooperation in a manner that will facilitate the collection of criminal or intelligence information, a primary focus of interrogation involves the use of approaches that might overcome the various forms of resistance described above. In this section, we review the influence of interrogative tactics for 
overcoming resistance, including the use of torture and coercive methods, and modern-day accusatorial methods involving psychological manipulation. We then describe more recent attempts to assess the effectiveness of rapport-based, information-gathering approaches.

Torture. Several researchers have evaluated claims of "effectiveness" with respect to the use of torture or coercion to overcome resistance and yield compliance with an interrogator's requests (Arrigo, 2004; Bell, 2008; Costanzo \& Gerrity, 2009; Hartwig, Semmel, \& Meissner, 2014; Pfiffner, 2014; Rejali, 2009). The consensus view is that the use of torture often fails as an effective means of successfully moving a resistant subject into a state of cooperation that may yield information of criminal or intelligence value. In 2006, the U.S. Intelligence Science Board conducted a systematic review of research underlying U.S. military and intelligence interrogation practices, including the use of torture (Fein, Lehner, \& Vossekuil, 2006). It concluded that the preponderance of studies and reports regarding the use torture tactics "weigh against their effectiveness" and that both theory and related research "suggest that coercion or pressure can actually increase a source's resistance and determination not to comply" (p. 35).

Cases in which torture does appear to "work" typically reflect a form of compliance in which the subject simply confirms an interrogator's belief and therein yields a confession statement of dubious accuracy. For example, the Senate Select Committee on Intelligence's (SSCI) Study on the Central Intelligence Agency's Detention and Interrogation Program (2014) examined 20 of the most notable "successes" offered by the CIA's program, concluding that there was little or no relationship between the use of "enhanced interrogation techniques" and the elicitation of intelligence. Further, detainees were shown to have provided false 
information or offered speculations in response to the application of torture, creating challenges to the use of any 'intelligence' gathered in such contexts. We note that several former U.S. government officials and contractors who have acknowledged their direct or indirect involvement in the CIA's interrogation program dispute the SSCI findings with respect to the effectiveness of coercive practices (Rodriguez, 2012; Mitchell, 2016; and Morell, 2016). Their arguments, however, lack any measure of scientific rigor.

While it is impossible to ethically evaluate the effectiveness of torture as an interrogation tactic, anecdotal reports and case studies of the operational use of such tactics offer only limited support for its purported efficacy in decreasing resistance and increasing compliance with an interrogator's requests (cf. Arrigo, 2004; Bell, 2008). For example, Stockdale (2001) estimated that more than $95 \%$ of U.S. personnel successfully resisted torture by the North Vietnamese, while Hoffman (1977) documented that torture by Nazi interrogators failed to gain compliance from high-level officials allegedly involved in plots to assassinate Adolf Hitler. Silverman (2001) examined more than 600 cases of judicial torture in France from the 1500s to the 1700 s, finding that torture produced confessions only $5 \%$ to $33 \%$ of the time. British interrogators similarly achieved success in only about $30 \%$ of interrogations at the London Cage using a variety of tactics that included torture (Cobain, 2005). Andrews (2001) describes experiments conducted by Nazi scientists in which they subjected concentration camp inmates to severe pain, extreme temperatures, and various drugs. Despite the variety of methods examined, they found no reliable means of gaining compliance. Finally, in a study supported by the U.S. Air Force, Biderman (1960) assessed the influence of interrogation tactics used by Communist Korea and China against more than 200 U.S. military prisoners of war. Biderman concluded that 
cooperation was more likely "in situations in which the ex-prisoner reported he was not subjected to overt threats or violence than in situations in which such coercion was reported" (pp. 143-144).

Recent systematic interviews with military and intelligence interrogators, including those who interrogated high-value targets, confirm these findings professionals frequently reference the use of torture as the least effective technique for gaining cooperation, with such tactics seen as more often producing resistance (Narchet, Russano, Kleinman, \& Meissner, 2016; Russano, Narchet, Kleinman, \& Meissner 2014). It is notable that these findings are consistent with the views of Markus Wolf, chief of the East German foreign intelligence service during much of the Cold War, who asserted that "interrogation...should serve to extract useful information from the prisoner...not to exact revenge by means of intimidation and torture" (Wolf \& McElvoy, 1997, pp. 261-62).

Psychological theory offers a perspective on why the use of torture or physical coercion so often fails to engender cooperation. For example, terror management theory demonstrates that people become more extreme in their belief systems (and therein resistant to change) when they are reminded of their mortality (cf. Burke, Martens, \& Faucher, 2010; Hirschberger \& Ein-Dor, 2006). Reactance theory also suggests that resistance is greater when one's freedom of action is constrained (Brehm, 1966) and recent modifications of this theory offer a nuanced perspective on the conditions under which the use of coercion or torture might yield compliance vs. increased resistance (Miron \& Brehm, 2006). First, motivation to resist appears to be key: When an expectation of success in resistance is maintained, a subject's resistance will remain strong (Wortman \& Brehm, 1975; Seligman, 1975). Second, if the subject lacks knowledge regarding the difficulty of maintaining resistance, they will continue 
to "mobilize as much energy as the goal of restoring freedom is seen to be worth" (Miron \& Brehm, 2006, p. 6). Finally, resistance can be maintained even when the difficulty of restoring the freedom is perceived to increase, though this motivation to maintain resistance will decline as the subject's perceived ability to reinstate freedom is lost.

Together, theory and data suggest that a subject's resistance to torture and physical coercion is likely determined by the perception of his or her ability to restore the freedom and to therein control their situation, and this perception will likely vary across individuals and situations. Khalid Sheikh Mohammed (KSM), the alleged mastermind of the 9/11 attacks who was waterboarded by the CIA at least 183 times, was said to have known the limits of the procedure - counting the seconds with raised fingers until it was completed. KSM maintained a high degree of resistance throughout his interrogations despite the repeated use of tactics regarded as torture. Even when he ultimately provided information to his interrogators, KSM remained uncooperative - as the SSCI (2014) determined that the information he provided was false.

As noted above, a small percentage of individuals subjected to torture will comply with an interrogator's requests. While torturers often equate the pain or intensity of a technique with its "efficiency" (see Rejali, 2009), research suggests that the perception of pain is subjective and can vary as a function of gender, culture, and life experience (cf. Hadjistavropoulos \& Craig, 2004). Further, pain intensity has been shown to be influenced by a variety of cognitive, emotional, environmental, and behavioral factors (see Gatchel et al., 2007). Of relevance to the influence of intense pain in torture, prior research has shown: (i) that one's beliefs about the extent of pain can influence perceived intensity (Arntz \& Claassens, 2004); (ii) that catastrophizing 
("an exaggerated negative 'mental set' brought to bear during painful experiences"; Sullivan et al., 2001, p. 52) is associated with an increased perception of pain intensity; and (iii) that perceived control over pain can influence both perceived intensity and tolerance (Samwel, Evers, Crul, \& Kraaimaat, 2006). As suggested by Arrigo (2004), an interviewee's motivational interpretation of his or her physical sensations (and the potential reactance one draws from it) could also likely determine the influence of torture in producing cooperation or increasing resistance.

Accusatorial Approaches. As described previously, harsh interrogation tactics also have a history within the U.S. criminal justice system, where "third degree" approaches involving physical abuse, incommunicado detention, deprivation of food, sleep, and medical attention, and explicit threats of harm were regularly used against subjects. Reforms in the U.S. during the 1930s and 1940s, including a Presidential Commission's "Report on Lawlessness in Law Enforcement," eventually diminished their use and led to the development of accusatorial interrogation approaches that emphasized psychological manipulation (Leo, 2008; Meissner \& Albrechtsen, 2007). This psychological approach is most popularly embodied in the Reid Technique of interrogation, first formalized by Inbau and Reid (1962) and highly influential within U.S. federal, state, and local law enforcement to this day (Inbau, Reid, Buckley, \& Jayne, 2013; see Kelly \& Meissner, 2015). Over the past decade, however, psychological and socio-legal research have demonstrated that the types of trickery and deception regularly used by law enforcement in some countries can produce a significant cost to social justice - they increase the likelihood of eliciting false confessions by the innocent (Kassin, 1997; Kassin et al., 2010; Lassiter \& Meissner, 2010; Meissner et al., 2014). 
Accusatorial tactics operate by manipulating a subject's beliefs about the relative consequences of confession and denial, and often involve the use of emotional "themes" that diminish feelings of guilt and lessen perceived culpability. Trickery and deception are the foundation of these approaches: in some countries police can lie to a suspect, present false evidence of their guilt, and manipulate their expectations regarding the potential consequences associated with confession (Kelly \& Meissner, 2015; for critiques of this approach, see Kassin, 1997, 2006; Kassin \& Gudjonsson, 2004; for social-psychological perspectives on the ensuing process of influence, see Davis \& Leo, 2012; Kassin, 2015; Madon, Guyll, Scherr, Greathouse, \& Wells, 2012).

Though lacking many of the physical elements of torture, the powerful effects of accusatorial approaches have been shown to produce both truthful confessions from the guilty and false confessions from the innocent (Kassin et al., 2010; Lassiter \& Meissner, 2010; Meissner et al., 2014, 2015). Such tactics as presenting subjects with false incriminating evidence (Kassin \& Kiechel, 1996; Nash \& Wade, 2009; Perillo \& Kassin, 2011) and minimizing the potential consequences associated with confession have been shown to increase the likelihood that both guilty and innocent individuals will confess (Horgan et al., 2012; Russano et al., 2005). Further, investigators who believe in a subject's "guilt" have been shown to conduct longer, more psychologically coercive interrogations, leading to a cycle of behavioral confirmation that encourages confession, particularly by the innocent (Kassin, Goldstein, \& Savitsky, 2003; Kassin, Meissner, \& Norwick , 2005; Meissner \& Kassin, 2002, 2004; Narchet, Meissner, \& Russano, 2011).

While accusatorial tactics are largely viewed as psychologically manipulative and therein successful at achieving compliance, a recent field study by Kelly et al. 
(2015) has suggested that the use of certain accusatorial tactics, such as the presentation of evidence, emotion provocation, and confrontation, can actually enhance resistance, leading to a subject's denials and refusal to cooperate. GoodmanDelahunty et al. (2014) have similarly found that the use of accusatorial tactics failed to enhance either cooperation or disclosure in a sample of high-value interrogations, and that an accusatorial framing of evidence reduced cooperation (see also, Walsh \& Bull, 2012, 2015).

In short, accusatorial tactics can, at times, induce compliance with an interrogators' request for an admission or confession - however, the diagnostic value of this information is often diminished (Kassin et al., 2010; Meissner et al., 2014). Minimization tactics that seek to lessen a subject's perceived culpability (and therein the consequences associated with confession) are particularly problematic for inducing false confessions by the innocent (Horgan et al., 2012). Recent research also suggests that certain maximization strategies (involving evidence presentation, emotion provocation, and confrontation) can produce resistance and therein diminish cooperation (Kelly et al., 2015). While U.S. law enforcement have embraced the use of these methods since the 1960s (Kelly \& Meissner, 2015), the aforementioned research (together with recent studies on alternative, rapport-based approaches described below) is only now beginning to influence the modern practice of interrogation in some countries (see Balko, 2017; Kolker, 2016).

Rapport-Based, Information-Gathering Approaches. In Great Britain, public response to a spate of miscarriages of justice involving false confessions became the catalyst for change, leading to the Royal Commission on Criminal Procedure in 1981. The commission determined that the factors producing these miscarriages of justice were occurring in the interrogation room - police frequently 
relied on techniques that were both physically and psychologically manipulative, and they lacked an existing protocol or training for non-coercive interrogations (Irving, 1980; Irving \& Hilgendorf, 1980). To address this situation, the Police and Criminal Evidence Act (PACE) of 1984 was created, which expressly limited the use of psychologically manipulative tactics and required that all interrogations be audio recorded (Bull \& Milne, 2004a). In 1993, the Royal Commission on Criminal Justice further reformed British interrogation methods by proposing the PEACE model, developed by a team of experienced detectives, informed by the available psychology (British Psychological Society, 2016). Each letter of the acronym "PEACE" represents a phase of interrogation that investigators should adhere to. In the “preparation and planning” phase, interrogators focus on organizing evidence and constructing a plan for the interview. During the "engage and explain" phase, the goal is to build rapport and to make the interviewee aware of the purpose of the interview. The third phase, "account," is the core of the interview. For compliant interviewees, investigators are encouraged to use the Cognitive Interview (Fisher \& Geiselman, 1992; Memon, Meissner, \& Fraser, 2010). For noncompliant interviewees, officers are instructed to use Conversation Management (Bull \& Milne, 2004b; Mortimer \& Shepherd, 1999) to encourage cooperation and discussion.

Contrary to an accusatorial style of interrogation, this approach has the goal of "fact finding" rather than that of obtaining a confession, and investigators are not permitted to lie to interviewees. After initiating the interview, subjects are encouraged to provide a complete account of their involvement or relation to the crime, and they are encouraged to speak freely, while close-ended questions are kept to a minimum (Bull \& Milne, 2004b; Mortimer \& Shepherd, 1999). Once the individual has provided his or her narrative and then been questioned about this (and other issues) 
while being challenged with evidence information known to the interviewer, the investigator offers the opportunity to correct any discrepancies (the "closure" phase). Finally, the investigator again compares the interviewee's statements to evidence, tries to clear up any remaining inconsistencies, and draws conclusions.

Over the past decade, researchers have begun to systematically evaluate the efficacy of rapport-based, information-gathering approaches such as the PEACE model (Meissner et al., 2010, 2015). Preliminary evidence suggests that utilizing such an approach not only reduces the likelihood of false confessions but also increases the elicitation of accurate information (Meissner et al., 2014). Field studies suggest that when investigators properly demonstrate the elements of the PEACE model, interviewees are more likely to provide complete accounts of their crimes (Walsh \& Bull, 2010b) and investigators are able to overcome initial denials (Walsh \& Bull, 2012). Laboratory studies also demonstrate that, when compared with accusatorial approaches, information-gathering approaches facilitate more cooperation and yield more accurate information from interviewees who are initially resistant (Evans et al., 2013a).

Central to the success of an information-gathering approach is the development of rapport - defined as "a positive and productive affect between people that facilitates mutuality of attention and harmony" (Bernieri \& Gillis, 2001, p. 69; for a review, see Vallano \& Schreiber Compo, 2015). In fact, surveys and interviews of law enforcement demonstrate wide support for the use of rapport and relationshipbuilding approaches (Kassin et al., 2007; Redlich, Kelly, \& Miller, 2014; Russano et al., 2014; Vallano et al., 2015). Evaluations of rapport development in the interrogation both point to its critical role in developing cooperation and eliciting accurate information. For example, Holmberg and Christianson (2002) interviewed 83 
sexual offenders about their interrogation, finding that interviews that involved an empathic and humanitarian perspective were associated with the elicitation of full confessions while those who were viewed as judgmental and dominant were more likely to elicit denials (see also Kebbell et al., 2010). Kelly et al. (2015) coded a sample of U.S. law enforcement interrogations and found that rapport and relationship tactics were associated with an interviewee's cooperation, and ultimately with confession to the crime (see also, Walsh \& Bull, 2012). Through systematic interviews of high-value detainees and interrogation professionals, GoodmanDelahunty et al. (2014) demonstrated that rapport strategies were significantly associated with (early) disclosure and the elicitation of accurate information. And finally, in what is likely the most complete evaluation of rapport and relationship building in an interrogation context, Alison et al. (2013, 2014b) evaluated five facets of rapport (autonomy, adaptation, evocation, empathy, and autonomy) drawn from the motivational interviewing literature (Miller \& Rollnick, 2013) in a sample of 418 separate interviews of 29 terrorism suspects in the UK. The authors found that an interrogator's ability to exhibit both conversational rapport and adaptive interpersonal skills (Birtchnell, 2002; Leary \& Coffey, 1954) were associated with a significant reduction in the likelihood of counter-interrogation (resistance) strategies by the subjects and an increase in the elicitation of investigative information. These empirical findings are consistent with the reports of several interrogators who have chronicled their experiences in questioning terrorist subjects (see Alexander, 2008; Soufan, 2011).

How is rapport developed in an interrogative context? A cogent review of rapport tactics has been offered by Abbe and Brandon (2014). In general, active listening and positive communication skills appear to be critical to facilitate a 
perception of openness, to express empathy and respect, and to humanize the conversation (Alison et al., 2013; Holmberg \& Christianson, 2002; Kebbell et al., 2010; Oxburgh \& Ost, 2011; Walsh \& Bull, 2012). Evans et al. (2013a) experimentally demonstrated that positive emotional approaches, such as selfaffirmations, expressing interest, and instilling calm, significantly reduced anxiety and increased feelings of rapport in a suspect interrogation (see also Davis, Soref, Villalobos, \& Mikulincer, 2016). Abbe and Brandon (2013) also note that rapport may be developed via selective principles of social influence (Cialdini, 2006), particularly by addressing interest, identity, or relational motivations (Kelman, 2006). In this context, Goodman-Delahunty and colleagues have found that liking and reciprocity were most frequently used to develop rapport in a sample of high-value detainees (i.e., subjects detained for terror-related activities), and that such tactics were significantly associated with information disclosure (Goodman-Delahunty \& Howes, 2014; Goodman-Delahunty et al., 2014).

Kleinman (2006) summarizes the distinction between methods of torture, coercion, or accusatorial approaches and that of a rapport-based, informationgathering approach by conceptually describing them as "control" and "rapport" models of interrogation: "the control model would obtain information only in direct response to the specific questions posed...in contrast, the rapport model is more likely to obtain not only similar kinds of information, but also additional information within the scope of the source's knowledgeability that was not necessarily addressed by the interrogator" (p. 136). Evidence is accumulating for the effectiveness of a rapportbased model for encouraging a productive exchange and minimizing reactance while offering empathy and autonomy to the interviewee. Rapport-based approaches also appear to facilitate the timely and appropriate (positive) confrontation of a subject to 
clarify statement-evidence inconsistencies (Alison et al., 2013; Alison et al., 2014b; Evans et al., 2013a), including facilitating an investigator's ability to leverage evidence in a strategic manner to promote disclosure (Tekin, Granhag, Strömwall, Giolla, Vrij, \& Hartwig, 2015; Walsh \& Bull, 2015).

Conclusion. Taken together, the available research suggests that the use of torture or physical coercion fails to produce timely and accurate information from a subject; instead, such tactics are less productive and less diagnostic than their advocates might lead us to believe and are also appear more likely to increase resistance by the subject. Accusatorial tactics can, at times, induce compliance with an interrogators' request for an admission or confession - however, the diagnostic value of this information is diminished (Meissner et al., 2014). Minimization tactics that seek to lessen a subject's perceived culpability are particularly problematic for inducing false confessions by the innocent and certain maximization strategies can produce resistance and therein diminish cooperation. In contrast, evidence is accumulating for the effectiveness of a rapport-based model for facilitating cooperation and minimizing resistance.

\section{Eliciting Information from Memory}

Interrogation in both the criminal and intelligence contexts serves as a vital means of gathering investigative information. What is commonly overlooked, however, is that any information of value that a subject can offer resides in his/her memory (Loftus, 2011). Therefore, just as technical intelligence officer or forensic scientist must diligently adhere to the principles of physics, biology, chemistry, computer science, and mathematics to effectively collect and analyze images, electronic communications, and various forms of trace evidence, human intelligence collectors and criminal investigators must be equally diligent in ensuring the methods 
they employ to elicit information from a subject adhere to the principles of cognitive and behavioral science and neuroscience with respect to the capacity, processes, and frailties of human memory.

To understand networks and to connect actors within an organization, subjects are often asked about meetings, interactions, actions and impressions related to both episodic (personal experiences involving a specific place and time) and semantic memory (general, conceptual knowledge as it may relate to their world), which could relate to information from months or even years prior. The primary goal of an investigator should be to elicit a complete and accurate account from the subject; however, such accounts do not typically emerge spontaneously and are also vulnerable to suggestion and error (Vrij, Hope, \& Fisher, 2014). While "blame" for poor interrogation outcomes have most commonly focused on the resistance and deception allegedly presented by a subject, we assert that it is poorly conducted interviews that create a more serious risk of eliciting unreliable information decreasing the amount of information elicited, destroying the credibility of the subject, and contaminating the investigative process.

Torture. Experimental data concerning the effect of torture on the elicitation of information from memory does exist, showing a clear pattern that such conditions have a negative effect on memory and recall. A particularly interesting experiment was carried out with 184 Special Operation warfighters in the U.S. Army enrolled in a Military Survival School (Morgan, Doran, Steffian, Hazlett, \& Southwick, 2006). Military Survival School training is one of the most rigorous forms of training experienced by special operations personnel. It is modelled after experiences of American prisoners of war in World War II and the Korean, Vietnam and Gulf wars. The exercises that the trainees underwent included confinement, food and sleep 
deprivation, extreme temperature variations and exposure to stressful interrogations under intensive and unremitting conditions. Unlike real-life interrogations in which subjects are often motivated not to report all the information they know and/or are motivated to lie, in this training the subjects' task was not to withhold any information but to be as complete and accurate as possible in their recall. The findings revealed that the physical, psychological, and emotional pressures experienced during the exercise resulted in significant memory impairment, including an inability to accurately recall previously learned information.

In another experiment, researchers evaluated the effect of a combination of standard torture techniques such as sleep and food deprivation, as well as temperature manipulation, on individuals' cognitive functioning (Lieberman et al., 2005). After being exposed to these stressors for a period of five days, the volunteers (with an average of nine years of active military service) showed severe impairment in their cognitive functioning, including their memory. Similarly, studies measuring the effects of sleep deprivation (e.g. Fenn, Gallo, Margoliash, Roediger, Nussbaum, 2009; Payne et al., 2012; Ratcliff \& Van Dongen, 2009) and extremes of cold and heat (e.g. Pilcher, Nadler, \& Busch, 2002) have also shown that such factors have a negative effect on the recall of learned material. In his cogent review of this research, O'Mara (2009, pp. 497-498) concluded that "prolonged and sustained sleep deprivation, in part because it results in a substantial increase in cortisol levels, has a deleterious effect on memory".

Torture is a threatening experience for subjects, and the general cognitive problems generated by these threatening conditions are problematic when conducting an interview for the purposes of eliciting accurate and comprehensive information. First, since memory retrieval is impaired under stress (see also Stawski, Sliwinski, \& 
Smyth, 2009), subjects under threat will either retrieve fewer experiences when they are asked open-ended questions or they will have more difficulty answering specific, closed questions. Second, when threatened, subjects are likely to pay attention to the interviewer's actions and demeanor, leading to divided attention or multi-tasking that is known to disrupt cognition, in general, and memory retrieval, specifically (Johnston, Greenberg, Fisher, \& Martin, 1970; Rohrer \& Pashler, 2003; Vredeveldt et al., 2011).

Another potential limitation of interviews conducted under high stress circumstances is that a subject's ability to monitor the quality of his/her own recollections may be impaired (e.g., Nelson, Dunlosky, White, Steinberg, et al, 1990), which can increase the likelihood of reporting false events. Such false recollections may come about because subjects base their recollections more on constructing from a schema (what might normally take place) than from the actual event or information to be recalled. Alternatively, subjects may commit source-monitoring errors, and confuse information associated with one task or event with a different task or event (Johnson, Hashtroudi, \& Lindsay, 1993). In sum, our cognitive machinery simply does not function well under conditions of threat or high stress.

The physiological processes associated with torture can also undermine reliable recall. O'Mara (2015), for example, applied a neuroscience perspective to the effect of torture and described how the brain reacts to fear, extreme temperatures, starvation, thirst and sleep deprivation. All these factors severely impair the brain systems responsible for memory, mood, and cognition. In particular, "chronic, prolonged and extreme stress...inhibits long-term potentiation (LTP; the biological process believed to underlie memory formation in the brain) and facilitates long-term depression (the inverse of LTP)...[and] causes hippocampal atrophy and, hence, 
impairs learning in humans and animals" (O'Mara, 2009, p. 498). Further, severe stressors at the time of retrieval can lead to increased cortisol levels that impair hippocampal function, producing impaired memory recall for both semantic and episodic information (for a review, see Hoscheidt, Dongaonkar, Payne, \& Nadel, 2013). Against this background, O’Mara pondered (2015) why anyone would imagine that the significant degradation in cognitive performance and mood imposed by such stressors would in some way facilitate recall, enhance memory, and improve motivation.

Accusatorial Approaches. In accusatorial interviews (and perhaps also in interrogations involving the use of torture) investigators often seek confirmation of facts they believe to be true and frequently suggest themes or narratives that the subject is simply asked to verify (Meissner \& Kassin, 2004; Meissner et al., 2014; Narchet et al., 2011). Unfortunately, the use of such confirmatory and leading questioning tactics (particularly when an investigator's assumptions are wrong) can have significant negative effects both for the memory of the subject and the ultimate conclusions of an investigation.

Once exposed to misleading information after an event, subjects can begin to make systematic errors when reporting what they have experienced (Frenda, Nichols, \& Loftus, 2011; Loftus, 2011), leading to the corruption or alteration of memory. The types of errors participants can make in misinformation studies include recalling the perception of non-existent items or offering incorrect descriptions of items they previously observed (clean-shaven man was remembered as having a moustache, and an individual with straight hair was remembered as having curly hair). Leading and confirmatory questioning can also facilitate the construction of false memories for events or experiences that never occurred (Loftus, 2011; Newman \& Garry, 2013). 
In a misinformation study utilizing the Special Operations Training School paradigm introduced in the previous section (Morgan, Southwick, Steffian, Hazlett, \& Loftus, 2013), some military personnel were given inaccurate information about their interrogator following a 30-minute interrogation. Although they could clearly see the interrogator during the interrogation and were interviewed only one hour after this interrogation, a large percentage of the interviewees exposed to the post-event misinformation (and many in the control condition) falsely identified a different individual as their interrogator.

Studies have also shown that false memories can be created in a manner that leads subjects to offer false criminal accusations against another individual (Loney \& Cutler, 2015), and that suggestive questioning approaches can induce subjects to generate false memories of a crime they had never committed (Shaw \& Porter, 2015; though see Wade, Garry, \& Pezdek, in press). The presentation of false or misleading evidence (see Nash \& Wade, 2009; Wade, Green, \& Nash, 2010) and suggesting that a subject has "memory problems" when they fail to recollect an event (Van Bergen, Jelicic, \& Merckelbach, 2008) are common accusatorial interrogation tactics that also play an important role in producing false memories. Such accusatorial approaches are believed to lead a subject to "distrust" his or her own memory and therein facilitate the production of a (false) confession (see Gudjonsson \& MacKeith, 1982). When used in combination with approaches that involve "shutting down denials" and preventing the subject from providing an account of the event that distances or exonerates him or her (Inbau et al., 2013), it becomes clear that accusatorial approaches are counterproductive from a memory elicitation standpoint. As discussed below, these approaches also hinder an investigator's ability to assess credibility and 
instead facilitate a biased perception of deception or guilt that is independent of veracity.

Information-Gathering Approaches. The Cognitive Interview (Fisher \& Geiselman, 1992) is a particularly effective information-gathering technique to obtain complete and accurate accounts from interviewees. In brief, the Cognitive Interview incorporates research-based principles to enhance three underlying psychological processes within an information-gathering interview: (a) the social dynamics between the interviewer and the respondent, (b) the interviewer's and the interviewee's cognitive processes, and (c) communication between the interviewer and the interviewee. Extensive laboratory and field testing conducted by several different laboratories around the world has shown the Cognitive Interview to be highly effective, eliciting approximately $35 \%$ to $50 \%$ more information than either typical police interviews or Structured Interviews (see Memon, Meissner, \& Fraser, 2010, for a meta-analysis, and Fisher, Schreiber-Compo, Rivard, \& Hirn, 2014, for a recent review.) A recent experimental study has also examined the effectiveness of an information-gathering approach with Cognitive Interview elements in eliciting guilty knowledge from resistant interviewees (Evans et al., 2013a). The authors demonstrated that such tactics led to significantly greater cooperation and information disclosure when compared with accusatorial tactics. Finally, research focusing on the recall by interviewers found that the interviewers' recall of the information provided by the interviewee was enhanced when a Cognitive Interview was used (Köhnken, Thurer, \& Zorberbier, 1994).

Given the robust effectiveness of the Cognitive Interview, some may wonder whether such interviews can be incorporated into harsh interrogations (e.g., torture or accusatory interviews). We believe this is not possible. The context of a harsh 
interrogation (the use of physical or psychologically coercive techniques aimed at gaining compliance with respect to directed responses regarding information objectives) differs markedly from that of a Cognitive Interview (a cooperative interview context in which the interviewee is recognized as holding the critical information in memory and is offered autonomy in providing it). Crucially, several elements that contribute to the Cognitive Interview's success may be difficult or impossible to implement in - or even adapt to - a threatening context. We first address the problem from the subject's perspective, and then from the investigator's perspective

Rapport. Rapport between an interviewer and subject is often considered the most important element in interviewing uncooperative respondents (Russano, Narchet, Kleinman, \& Meissner, 2014). Moreover, it has the backing of empirical testing, which shows rapport increases the amount of information witnesses report (Collins, Lincoln, \& Frank, 2002; Vallano \& Schreiber Compo, 2015). Further, rapport-building tactics can be useful in enhancing recall by protecting against the potentially negative influence of post-event misinformation. This positive effect occurred only when rapport-building took place prior to the introduction of misinformation, but not subsequent to its presentation (Kieckhaefer et al., 2013; Memon, Holley, Wark, Bull, \& Köhnken,1996). It is difficult to imagine, however, how an aggressive tormenter can possibly establish or maintain rapport with the subject.

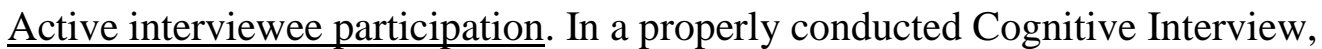
the interviewee is made to feel that he or she plays a more important role than the interviewer. As a result, the interviewee is expected to play an active role by generating information rather than simply answering the interrogator's questions. In a 
harsh interrogation procedure, the social dynamics are just the opposite - the interviewer plays the dominant role of asking closed-ended and confirmatory questions and the subject plays a secondary, and often compliant, role of answering the interrogator's questions. As a rule, this kind of question-answer format is an inefficient and ineffective way to gather information.

Internal interviewee focus. Ideally, interviewees will direct their mental resources inwardly toward the source of their memory, and not outwardly toward the interviewer. To the degree that a subject is attending to the interviewer, which is likely to occur in a harsh interrogation because the interviewer is the source of the interviewee's discomfort, the subject cannot search through his or her memory with focused concentration. Such non-focused memory retrieval is inefficient and is likely to yield either an incomplete or a non-detailed recollection (Vrij, Hope, \& Fisher, 2014).

A related factor is that interviewees should not be distracted by physically or psychologically disruptive thoughts during the interview, so that they may concentrate their cognitive resources exclusively on memory retrieval. If subjects are distracted by torture or psychological manipulation, which is likely to occur under harsh interrogation practices, subjects will not be able to make efficient use of their cognitive resources.

Closing eyes. People tend to close their eyes to improve concentration (Glenberg, Schroeder, \& Robertson, 1998), and, relatedly, closing one's eyes is known to enhance recall (Vredeveldt, Hitch, \& Baddeley, 2011). Hence, in a Cognitive Interview, after having established rapport with the subject, the interviewer may ask the interviewee to close his or her eyes before attempting to recall an event. To be willing to close their eyes, the individual must have complete trust in the 
interviewer. Not surprising, this will not happen if the subject feels threatened by the interrogator, as is inevitably the case in a harsh interrogation.

Permitting "I Don't Know" responses. People generally have good metacognition: they know what they know and they know what they don't know (e.g. Paulo, Albuquerque, \& Bull, 2016). If interviewees are permitted to say “I don't know" when that is the appropriate response, they will rarely report events incorrectly (Evans \& Fisher, 2011). If, however, subjects feel threatened by not responding to questions, as commonly occurs in a harsh interrogation, they may generate incorrect responses.

Varied retrieval requires working memory. One element of the Cognitive Interview is to encourage interviewees to report events in several different ways, e.g. chronological and reversed order. Such varied retrieval, and in general understanding the interviewer's instructions, likely requires individuals to make efficient use of working memory. An unavoidable reality of harsh interrogation practices is that they introduce intense stress, either as applied in the context of the interview or as a product of long-term sleep deprivation, which impairs working memory (e.g., Lopez, Previc, Fischer, Heitz, \& Engle, 2012; Morgan, Doran, Steffian, Hazlett \& Southwick, 2006).

Eliciting unsolicited information. An important element of the Cognitive Interview is to elicit unsolicited information, and not to restrict interviewees merely to answering the interviewer's questions. This is accomplished in part by developing solid rapport and by instructing interviewees to take the dominant role within the interview. Given the uncooperative nature of a harsh interrogation and the subject's conditioning to answer only those questions asked, it is unlikely that subjects will within it generate any unsolicited (but truthful) information. 
The above elements refer to the extent to which harsh interrogation practices generate conditions that are likely to prevent an interviewee from providing information efficiently. However, the interviewer, too, may have difficulty conducting the interview if he or she is in a highly-aroused state, which might be expected to occur in a harsh interrogation.

$\underline{\text { Stress impairs encoding. Heightened stress impairs people's ability to encode }}$ new information (Morgan, et al., 2004). As such, interviewers may not be able to process thoroughly the details being reported by the subject. This could be particularly the case for non-central, but important, details embedded within a subject's recollection (Wagenaar \& Groenweg, 1990).

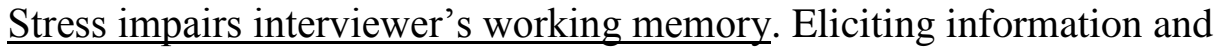
assessing credibility are two critical tasks demanded of the interviewer. To complete these tasks, interviewers must keep track of many signals during the interview, including the interviewee's responses and the next set of questions, as well as maintaining an overall strategy while conducting the interview. Interviewers also need to be adaptive - modifying the interview questions or approach when unexpected information arises. If interviewers are stressed, as they may be in a harsh interrogation, their ability to process signals effectively and to effectively modify their strategy, is likely to be impaired.

Interviewers speak too rapidly when aroused. Interviewers should speak slowly when conducting a Cognitive Interview, as this facilitates an interviewee carrying out the requested cognitive processes while listening to the interviewer. For example, an effective method of recalling an earlier event is to reinstate the context in which the event occurred (Tulving \& Thomson, 1973). For interviewers to implement this strategy effectively, they need to speak slowly so that interviewees will be able to 
place themselves back in the original context while being guided by the interviewers' instructions. If interviewers are stressed, however, their speech rate is likely to increase (Pope, Blass, Siegman, \& Raher, 1970), thereby rendering the subject's task more difficult.

Pause after the interviewee stops recalling. One element of a properly conducted Cognitive Interview is that interviewers should pause for several seconds after an interviewee stops recalling an event, as such pauses can assist interviewees to retrieve or report additional information. Allowing for long periods of silence, however, seems unlikely for aggressive interrogations, as investigators may interpret such silence as a subject's attempts to intentionally withhold information. As such, interrogators' follow-up questions are likely to occur shortly after the subject stops speaking, thereby shutting off any delayed recollections an interviewee might provide.

Conclusion. Overall, the threatening and adversarial nature of harsh interrogation is often inimical to the goals of fostering efficient cognition. Harsh interrogation will therefore reduce the likelihood that respondents will provide reports that are extensive, detailed, and accurate - even in instances where that is the respondent's self-determined objective. If the interrogator's goal is to seek confirmation of facts, enhanced interrogation will only serve to validate the narrow set of assumptions that an interrogator holds. Confirmatory, leading, and suggestive questioning tactics associated with accusatorial approaches are also likely to corrupt a subject's memory and lead to false confessions (particularly if the interrogator's assumptions about the facts are inaccurate). In this way, both harsh interrogation tactics and accusatorial approaches are counterproductive to the elicitation of extensive, detailed, highly accurate information. A research-based alternative 
involving rapport-based, information-gathering approaches that incorporate elements of the Cognitive Interview is more likely to yield robust and reliable information from a resistant interviewee. Further, as discussed in the next section, the use of information-gathering approaches offers a corollary benefit by enhancing the assessment of credibility in suspect interviews (Geiselman, 2012; Meissner et al., 2015).

\section{Assessing Credibility}

Although it is generally accepted that subjects sometimes lie during criminal and intelligence interviews, it is perhaps less widely recognized why they do this. A common belief is that subjects will lie simply to conceal an illegal or shameful past behavior, particularly when criminal or legal consequences are present. Beyond this, however, subjects may also consider their interrogators to be their enemy or to not represent their best interests, and thus lie to protect themselves or their family, friends, or collaborators. Subjects may also lie for political or personal gain. A notable example of this involved an Iraqi engineer, Rafid Ahmed Alwan al-Janabi (codenamed 'Curveball'), who fabricated elaborate tales of mobile bioweapons trucks and clandestine factories when talking to German and American intelligence officials as part of an attempt to secure asylum in Germany for himself and his family (Chulov \& Pidd, 2011). Intelligence sources (those related to criminal or national security interests) sometimes receive money or obtain other rewards from their handlers if they can provide valuable information. Sources may decide to fabricate such intelligence to continue receiving these (at times significant) rewards.

In this section, we discuss credibility assessment in criminal and intelligence interviews through observing behavior or examining speech content. There is little known about lie detection in torture interviews. The nature of accusatory interviews 
leads investigators to be reliant upon nonverbal cues to deception; however, such cues to deceit are faint and unreliable. The nature of information-gathering interviews offers investigators the opportunity to attend to verbal cues to deceit - the available research suggests that such cues have great potential in lie detection. ${ }^{1}$

Torture. With the exception of one study (Houck \& Conway, 2015) we are not aware of any systematic studies that assess the effect of torture on a subject's decision to lie. However, numerous real-life cases are available in which subjects decided to lie rather than tell the truth after being exposed to torture. As described above, KSM, the alleged mastermind of the 9/11 attacks, allegedly provided false information when he eventually began to talk during his waterboarding sessions (SSCI, 2014). Mark Fallon, the chief investigator of a Department of Defense task force with forward deployed elements in Afghanistan, Iraq, and Guantanamo Bay, Cuba, oversaw thousands of interrogations of terrorist suspects, including an unknown number through direct observations. He concluded that resorting to abusive techniques was likely to greatly increase the chance that subjects would lie to appease their interrogators, leading to the collection of inaccurate and unreliable information (Fallon, 2015). Fallon notes that these false leads, coerced from subjects, were often believed and that the comprehensive efforts to follow-up on them resulted in a significant waste of resources.

For interrogators to distinguish between truthful and deceitful responses, they must elicit diagnostic nonverbal or speech related cues to deceit. The problem, of course, is that physical, emotional, or psychological abuse almost certainly will have a pronounced effect on a subject's nonverbal behavior and this effect is likely to overshadow any small effect that the subject's veracity status may have on his or her nonverbal behavior. The ability to detect lies by assessing speech content depends 
upon whether subjects exposed to harsh interrogation methods are likely to give short or long answers. Longer narratives are more likely to reveal verbal cues to deceit, as we will discuss below.

Accusatorial Tactics - Anxiety and Nonverbal Behavior. A central tenant of accusatorial approaches to interrogation is that, given a context in which the subject is confronted by a confident investigator with significant evidence of culpability, the individual will experience anxiety and any subsequent attempts to lie or conceal information will result in nonverbal cues of deceit. The few studies examining behavioral responses in accusatory interviews present a bleak picture regarding the veracity of this proposition, particularly regarding the "nervous responses' (e.g., gaze aversion and behavioral fidgeting) that advocates of accusatorial approaches generally attend to (Strömwall, Granhag, \& Hartwig, 2004). In several experimental laboratory studies using an accusatory setting, indicators of nervous behaviors did not differentiate between liars and truth tellers (Vrij, 1995, 2006; Vrij, Mann, \& Fisher, 2006). More generally, a robust literature on cues to deception similarly offers a pessimistic view on the relationship between nonverbal behavior and deception. Meta-analyses summarizing the findings of over more than one hundred separate research studies conclude that nonverbal cues to deceit, particularly those promoted in interrogation training manuals (e.g., gaze aversion, shifting position and fidgeting) are faint and unreliable (DePaulo et al., 2003; Sporer \& Schwandt, 2006, 2007).

Of course, the stakes for liars (negative consequences of being disbelieved and positive consequences of being believed) are rather low in laboratory studies, and perhaps more pronounced differences in nonverbal behaviors between truth tellers and liars will emerge in high-stakes situations. Although a reasonable proposition, a 
recent meta-analysis showed that such differences in nonverbal behaviors are equally small in both low- and high-stakes situations (Hartwig \& Bond, 2014). Liars may well display nonverbal cues indicative of anxiety during high-stakes interviews, but truth tellers are also anxious in such interviews and, consequently, display the very same cues as liars (Bond \& Fahey, 1987; Evans et al., 2013). As a strategic framework for assessing credibility, anxiety-based lie detection techniques are problematic - they lack a sound theoretical underpinning as to why truth tellers and liars would differ from each other in their anxiety-related responses (National Research Council, 2003).

Research examining people's ability to detect deceit by observing other people's behavior has reached a similar dead end. The fundamental nature of accusatory interviews, according to the few studies in this area, makes it difficult to accurately distinguish truth tellers from liars. In none of the lie detection studies in which an accusatory interviewing setting was employed were observers able to distinguish between truth tellers and liars (Vrij, 1994; Vrij, Mann, Kristen, \& Fisher, 2007; Zimmermann et al., 2010). Moreover, Vrij et al. (2007) found that observers made more false positives (false accusation of truth tellers) when observing accusatory interviews compared to information-gathering interviews. One reason for this finding is that truth tellers display nervous behaviors when falsely accused of wrongdoing (Bond \& Fahey, 1987), which may make them look suspicious. Further, research has found that investigators who are trained in accusatorial interrogation methods are more likely to demonstrate a bias towards perceiving deception and guilt in forensic interviews (Kassin et al., 2005; Meissner \& Kassin, 2002, 2004). This investigative bias is an important finding because once innocent interviewees are mistakenly identified as guilty, they are more likely to endure longer and more pressure-filled interrogations (Kassin et al., 2003), leading to an increased risk of false 
confessions (Narchet et al., 2011).

Bond and DePaulo (2006) used a meta-analytic approach to examine people's ability to detect truth and lies. Across nearly 25,000 observers, studies demonstrated an average accuracy rate of $52 \%$ in correctly classifying truth tellers and liars when someone could only see (but not hear) the target person, whereby a 50\% accuracy rate would be obtained by chance alone. These accuracy rates are significantly less than the $63 \%$ accuracy rate obtained when participants could only listen to (but not see) the target person (Bond \& DePaulo, 2006) - suggesting, once again, that verbal content cues are more diagnostic in discriminating liars and truth tellers when compared with nonverbal behavior. Whether someone is a professional lie catcher or a layperson has no effect on accuracy, though professionals (e.g., police investigators) are more confident in their judgments than laypersons (Aamodt \& Custer, 2006; Vrij, 2008).

In theory, there are two possible explanations for the low accuracy rates when assessing nonverbal behavior. First, there is little difference in the nonverbal behaviors displayed by truth tellers and liars. Second, people look for the wrong cues and fail to spot the differences that exist. In their meta-analytic lens analysis, Hartwig and Bond (2011) examined these two possibilities and concluded that people perform poorly because the behavioral differences between truth tellers and liars are too small to make the task achievable. This finding also explains why training people to detect lies by informing them about 'diagnostic nonverbal cues to deceit' has hardly any positive effect (Hauch, Sporer, Michael, \& Meissner, 2014).

It is a lamentable state of affairs - and an alarming indicator of how little science has been permitted to inform conventional interviewing practices - that claims regarding the efficacy of nonverbal behavior in revealing deception are so widespread. An simple internet search will produce an expansive number of popular 
articles expressing this idea, while many books also seek to convey this idea, including Lie spotting (Meyer, 2010) and Spy the lie (Houston, Floyd, \& Carnicero, 2012). Nonverbal lie detection tools such as the Behavior Analysis Interview (BAI) (Horvath, Blair, \& Buckley, 2008; Horvath, Jayne, \& Buckley, 1994) and Ekman's (1985) approach of observing facial expressions and involuntary body language, the approach utilized by the fictitious character Cal Lightman in the Fox network TV series Lie to $\mathrm{Me}$, are frequently taught to practitioners in many (but not all) countries, including law enforcement, military, and intelligence personnel. There is no evidence that the BAI or lie detection through observation of micro-expressions work. Inbau et al. (2013) cited the Horvath et al. (1994) study to support the efficacy of the BAI; however, that field study is, according to Horvath and colleagues themselves, problematic due to the lack of ground truth (that is, uncertainty about which of the 60 interviewees examined in the study were actually lying). A laboratory experiment testing the BAI procedure found no support for its efficacy (Vrij, Mann, \& Fisher, 2006). Further undermining support for credibility assessment based on nonverbal cues, Paul Ekman (who introduced the micro-expression lie detection approach) has never published data showing that it works. Porter and ten Brinke (2008) examined the relationship between micro-expressions and deception in a laboratory experiment and found that micro-expressions very rarely occurred (only in 14 out of 697 video fragments, or $2 \%$ of the segments examined) and that both liars and truth tellers displayed them.

Accusatory interviews also offer little opportunity for verbal cues to deception to emerge primarily because interviewees say relatively little and/or are given very few chances to speak in such interviews (Meissner et al., 2014). Of key importance here is that verbal cues are more likely to occur when interviewees are encouraged to 
provide larger volumes of information, as their words are the carriers of verbal cues to deceit (Vrij, Mann, Kristen, \& Fisher, 2007). The finding that subjects say relatively little in accusatory interviews is likely the result of U.S. interrogation training that promotes confirmatory questioning strategies and the "shutting down" of denials, while also encouraging investigators to induce anxiety and identify nonverbal signs of deception (often related to anxiety) (Vrij \& Granhag, 2007; Vrij, Granhag, \& Porter, 2010).

Training manuals frequently encourage this behavioral assessment by making the claim that more than $70 \%$ of a message communicated between persons occurs at the nonverbal level (Vrij, 2014). This claim is primarily based on Mehrabian's (1971) work, who studied the communication of single spoken words. If people say little, speech content cannot play a primary role in the exchange of information. It creates what can only be described as a vicious circle: Because the subject is given little opportunity to speak, the interviewer has few options to assess credibility by means of an evidence-based strategy (verbal cues) and, instead, embraces a method (nonverbal cues) that empirical research has disputed as reliable.

Verbal cues to deceit are typically more diagnostic than nonverbal cues to deceit (DePaulo et al., 2003; Vrij, 2008). This explains the higher accuracy rates when listening to speech compared to observing behavior reported above. In also explains why in one of the rare studies of ecologically valid, high-stakes lying/truth-telling, it was found that police officers assessing video recorded interviews with suspects in real life interviews achieved detection accuracy rates significantly above chance level, especially those who indicated that they relied on speech cues (Mann, Vrij, \& Bull, 2004). And in a recent study it was found that when Japanese police officers accurately judged the participants' veracity, they were more likely to rely upon verbal 
than nonverbal cues (Wachi et al., 2017). It also explains why training people to detect lies by informing them about 'diagnostic verbal cues to deceit', has a larger effect than informing them about nonverbal cues (Hauch, Sporer, Michael, \& Meissner, 2014).

Taking into account the different strategies employed by truth tellers and liars explains why nonverbal cues are less diagnostic than verbal cues to deception. Nonverbally, truth tellers and liars will try to suppress behaviors they believe appear suspicious (mostly signs of nervousness). This means that truth tellers and liars will both use the same strategy as far as their behavior is concerned (Hartwig, Granhag, Strömwall, \& Doering, 2010; Vrij, Leal, Mann, \& Granhag, 2010).

It is a different story for speech content (Hartwig, Granhag, Strömwall, \& Doering, 2010; Vrij, Leal, Mann, \& Granhag, 2010). A truth teller's strategy is to 'tell it all' and to give as much detail as they can remember, whereas a liar's strategy is to avoid incriminating themselves by, for example, being vague, providing evasive information, or by offering little detail (Hartwig, Granhag, \& Strömwall, 2007). The different strategies used by truth tellers and liars are reflected in the content of their speech, leading to differences between truth tellers and liars, that strategic interviewing tactics, inherent to an information-gathering approach, can elicit.

Information-Gathering Approaches - Analyzing Speech. Two studies have directly compared the influence of information-gathering and accusatorial approaches in their ability to detect truths and lies. One study demonstrated a higher accuracy rate in information-gathering interviews (Zimmermann et al., 2010), whereas the other study found no differences in accuracy rates, but a higher percentage of false positives in the accusatory interviews (Vrij, Mann, Kristen, \& Fisher, 2007). We addressed the negative consequences of false positives for innocent interviewees above (see 
Meissner \& Kassin, 2004). In terms of nonverbal cues, no clear picture emerged between information-gathering and accusatory interviews, but this is perhaps not surprising given the generally weak relationship between nonverbal behaviors and deception more generally. What is clear is that the information provided, and therein the speech content of the interviewee, significantly increases when an informationgathering approach is employed (Evans et al., 2013a).

Recent research has demonstrated that information-gathering interviews can actually enhance the elicitation of diagnostic cues to deceit, particularly verbal cues, when specific questioning protocols are employed (Vrij \& Granhag, 2012). The protocols that are particularly promising include the Strategic Use of Evidence (SUE) (Granhag \& Hartwig, 2008, 2015; Hartwig, Granhag, \& Luke, 2014), cognitive credibility assessment (Vrij, Fisher, \& Blank, 2015; Vrij, Fisher, Blank, Mann, \& Leal, 2016; Vrij, Granhag, Mann, \& Leal, 2011), and the Verifiability Approach (Nahari, Vrij, \& Fisher, 2014a, b). A common theme across these questioning techniques is that they aim to make lying a more difficult task.

SUE is premised on the operational presumption (supported by experimental research) that truth tellers are forthcoming in interviews, whereas liars do not wish to be linked to incriminating evidence and thereby use an "avoid and escape" strategy. The core of the SUE technique is to ask questions related to the evidence without specifically mentioning the evidence, e.g., "When you were in the shopping mall, did you visit the book store?" (not referring to the CCTV evidence that the person visited the book store). According to a meta-analysis of the SUE-technique (Hartwig, Granhag, \& Luke, 2014), liars are more likely than truth tellers to provide a statement that contradicts the evidence (statement-evidence inconsistencies, e.g., denying having been at a certain place at a certain time). Further, when liars begin to realize 
during the interview that investigators possess evidence (such as the CCTV evidence), they will attempt to change their statement so that it will accommodate this evidence (e.g., from a denial to having visited the book store to an admission to having done so) resulting in more within-statement-inconsistencies (Hartwig, Granhag, \& Luke, 2014).

The cognitive credibility assessment approach contends that certain instructions can be more difficult to follow for liars than truth tellers. This technique comprises three key elements. First, lying is often more difficult than truth-telling in interview settings (Christ, Van Essen, Watson, Brubaker, \& McDermott, 2009), and investigators can exploit this by making the interview setting more difficult by making additional requests of the interviewee designed to increase "cognitive load." If lying already requires more cognitive resources than truth telling, liars will have fewer cognitive resources left over to deal with such additional requests. For example, when interviewees were asked to recall their story in reverse order - a difficult task lie detection was better than when they recalled their stories in chronological order (Evans, Michael, Meissner, \& Brandon, 2013b). In another study, some truth tellers and liars were asked to squeeze a spring-loaded handgrip as long as possible - an exercise which makes people fatigued over time - whereas other truth tellers and liars did not have to do this. Under these circumstances, reaction times were slower for liars than for truth tellers (Debey, Verschuere, \& Crombez, 2012).

The second element of the cognitive credibility assessment approach encourages interviewees to say more by, for example, using a 'model statement' of a detailed response. According to social comparison theory (Festinger, 1954; see also Cialdini, 2006), in the absence of objective information, individuals will compare themselves to others. In interview settings, interviewees are often uncertain about 
what is required of them - for example, with respect to the amount of information they need to provide (Vrij, Hope, \& Fisher, 2014). In such contexts, individuals are likely to use other sources as a point of reference (Lawrence, 2017). In this case, providing an interviewee with a detailed model statement leads them to recognize that what they planned to provide is less detailed than what the interviewer is expecting from them (Ewens et al., 2016b). This results in truth-tellers adding more plausible detail to their narratives (Leal, Vrij, Warmelink, Vernham, \& Fisher, 2015). By comparison, liars lack the necessary imagination or creativity to add the same amount of plausible detail as truth tellers, or they may be reluctant to provide the additional information given that it may expose possible deception to investigators.

The third element of the cognitive credibility assessment approach is to ask unexpected questions. Liars prepare themselves for interviews by thinking of plausible answers to possible questions (Hartwig, Granhag, \& Strömwall, 2007). The difficulty liars face is that they do not know what questions will be asked. Investigators can exploit this by asking a mixture of questions that liars have likely expected along with those that are likely unexpected, yet relevant to the given context (e.g., questions about the planning of activities). Typically, truth tellers and liars provide the same amount of detail when answering expected questions, whereas liars are less detailed than truth tellers when answering unexpected questions (Knieps, Granhag, \& Vrij, 2013).

A meta-analysis of 38 studies examining 'cues to deceit' revealed that the cognitive credibility assessment approach was more effective in eliciting diagnostic cues to deceit (e.g., lack of detail, plausibility, and consistency) than a standard approach (Vrij, Fisher, Blank, Leal, \& Mann, 2016). Similarly, a meta-analysis of 14 studies examining 'accuracy rate' in distinguishing liars and truth tellers (accuracy 
rates based on human observers and computer software combined) revealed a superior accuracy rate in the cognitive credibility assessment approach (71\%) compared to the standard approach (56\%) (Vrij, Fisher, \& Blank, 2015). Finally, in a training study, experienced law enforcement personnel in England and Wales successfully increased their ability to distinguish between truth tellers and liars after using the cognitive credibility assessment approach (Vrij, Leal, Mann, Vernham, \& Brankaert, 2015).

The Verifiability Approach is based upon different strategies truth tellers and liars employ in investigative interviews (Granhag \& Hartwig, 2008). Truth tellers are inclined to be open and to tell all they remember about their activities. In contrast, liars are motivated to withhold key information from the investigator, particularly information they believe incriminates them or information that could reveal that what they have provided is false. If liars are motivated to omit information that could reveal their deception, they will be especially likely to avoid details that an investigator could check - so-called verifiable details (e.g., "I phoned my friend John at 10:30 this morning"). The Verifiability Approach encourages investigators to look for details that can be checked: i) activities carried out with or witnessed by identifiable or named persons who the investigator can consult, ii) activities that, according to the interviewee, can be shown on CCTV cameras, or iii) activities involving technology that can be traced (e.g., the use of debit or credit cards, mobile phone, tablets or computers). Research confirms that truth tellers include more verifiable details into their accounts than liars (Nahari, Vrij, \& Fisher, 2014a), and this effect can be strengthened if interviewees are asked prior to the interview to include details that an investigator can check (Harvey, Vrij, Nahari, \& Ludwig, in press; Nahari, Vrij, \& Fisher, 2014b). 
All of the techniques described in this section are situated within an information-gathering context. Whether they could also be implemented in interrogative contexts that induce torture or apply accusatorial approaches will depend on how truth tellers respond in such contexts. The techniques should work best when truth tellers have a vivid and detailed memory of the experiences they are interviewed about. As we saw above, truth tellers' memory could be negatively impaired when they are stressed, which is more likely to happen in torture and accusatorial interviews than in information-gathering interviews. The techniques are also more efficient when truth tellers receive the opportunity and encouragement to provide a complete account of their experiences. The techniques are thus likely to be less effective in interview settings in which investigators offer themes and narratives that interviewees simply confirm or deny and in which interviewees are given few chances to speak (e.g., accusatorial interviews).

Conclusion. Deception studies examining torture or accusatorial tactics are rare; however, the available evidence shows that they are not beneficial in terms of cues to deceit and lie detection. They focus on analyzing nonverbal cues to deceit, which research has shown to be faint and unreliable. Analyzing speech content is the most reliable method of lie detection; however, interviewees must give extensive narratives for verbal cues to deceit to occur, something that is unlikely to occur in harsh interrogations. Information-gathering interviews are the preferred method for verbal lie detection and the ability to detect deceit. They can be further enhanced by introducing cognitive-based interview protocols.

IV. Why do laypersons, policy makers and interrogators believe that enhanced techniques will work? 
If 'enhanced interrogation tactics' lack efficacy, increasing the risk of false confessions and faulty intelligence, then why do some laypersons, policy makers, and military/civilian interrogators believe that these tactics work? In this section, we explore the variety of social and cognitive psychological mechanisms that can shed light on this issue, and the research that has been conducted to assess the conditions that bolster individuals' support for torture.

One reason why laypersons and policy makers may think torture works is that they perceive that they themselves would likely talk when being tortured. This may lead to the idea that torture will be effective as people tend to perceive a "false consensus" with respect to the extent to which their own responses are shared by others: 'If I will talk while being tortured, others will talk too', the so-called false consensus effect (Ross, Green, \& House, 1977).

Another reason why laypersons and policy makers may think torture works is that it seems to work in Hollywood films, at least with the 'bad guys'. A good example is Zero Dark Thirty, a film about the hunt for Osama bin Laden. It includes a dramatic scene of a suspect being waterboarded and then providing information that eventually leads to bin Laden's location. Such a scene seems not to have occurred in the actual investigation. Laypersons may well be influenced by such films and be led to believe that torture is effective.

In addition, when thinking about torture, laypersons and policy makers perhaps think about a ticking bomb scenario: someone who has critical information about an immediate terrorist threat. In such a scenario, a quick outcome of the interrogation is needed and perhaps people believe that subjects will start talking soon during torture interrogations. People may also think that harming one individual is 
justified in such a scenario because it could prevent a terrorist attack that could potentially harm many more people.

Perhaps laypersons and policy makers think that a country's ability to successfully collect information to support national security interests would be compromised if torture were to be officially - and publicly - dismissed as a policy option. Inherent to this argument is the belief that a detainee is more likely to cooperate based solely on their expectation that they would be tortured if they resisted an interrogator's prompts. However, if true, then such a belief in the mind of a detainee has the potential to engender the same degree of anxiety and psychological/emotional trauma that we have argued undermine meaningful levels of cooperation, diminish and/or corrupt memory, and impair judgment as that produced by actual torture.

Moreover, the support for torture increases as a function of psychological distance. For example, being personally close to a victim (e.g. a loved one) who can be saved by torturing a perpetrator, increased support of torture of the perpetrator (Houck \& Conway, 2013) and increased estimates of the effectiveness of such torture (Houck, Conway, \& Repke, 2014).

Finally, support for the use of torture may be motivated by a desire for retribution. Specifically, to the extent that an interviewee is judged guilty or otherwise involved in a heinous act, torture tactics may serve as a means of administering punishment, thereby satisfying a basic intuition-based sense of justice - regardless of whether it serves more reason-based utilitarian purposes such as deterrence (see Carlsmith, 2006; Carlsmith \& Darley, 2008). An experiment involving a national sample of American respondents revealed that a layperson's desire for harsh interrogation is mediated more by perceptions of the interviewee as immoral and, 
therefore, deserving of punishment, than by the presumed effectiveness of the interrogation methods (Carlsmith \& Sood, 2009). Illustrative of this idea is a statement by U.S. President Donald Trump describing his support of waterboarding: "Would I approve waterboarding? You bet your ass I would. In a heartbeat. I would approve more than that. It works. And if it doesn't work, they deserve it anyway for what they do to us." (The Guardian, November 23, 2015). ${ }^{2}$

With respect to interrogators, it is important to note the context in which "third-degree" and enhanced interrogation tactics are used. Often the triggering event is a heinous and public crime, an act of terrorism, or an urgent wartime need for intelligence gathering. In these situations, investigators are likely to exhibit a pressing need for cognitive closure (NFCC) - an epistemic motivation that increases the desire to resolve ambiguity and reach certainty on judgments and decisions (Kruglanski, 2004). Although individuals differ in their characteristic levels of NFCC, certain situational factors, such as time pressure and fatigue, may also increase these tendencies.

Investigators afflicted by NFCC may become overly motivated to speedily resolve the case they are working on and hence more likely to resort to extreme tactics. Research shows that a high NFCC leads people to become more dogmatic (Webster \& Kruglanski, 1994), to form strong first impressions that are resistant to change (Pierro \& Kruglanski, 2008; Webster, Richter, \& Kruglanski, 1996), and to seek out less information before making final decisions (Van Hiel \& Mervielde, 2002; Webster et al., 1996). Not surprisingly, NFCC, can serve as a proxy for closedmindedness and can increase the tendency for people to: (i) commit the fundamental attribution error - a robust tendency to underestimate the role of situational factors on other people's behavior (Webster, 1993); (ii) perceive others in stereotypic terms 
(Dijksterhuis, Van Knippenberg, Kruglanski, \& Schaper, 1996); and (iii) reject others who dissent, thereby enabling work groups to produce a "shared reality" that facilitates closure (Kruglanski, Pierro, Mannetti, \& De Grada, 2006).

It is in the context of a strong NFCC that interrogators are likely to employ all tools at their disposal to solve a case. In a study that lends support to this hypothesis, Häkkänen et al. (2009) asked investigators examining violent crimes to rate the value of various tactics in hypothetical interrogations of a homicide suspect. Two types of tactics were included on the list: "humane" and "dominant." Results showed that in a case presented as lacking hard evidence, investigators who scored as high (vs. low) in NFCC rated both types of tactics as more important to the task. This result is instructive. If NFCC leads interrogators to adopt a "do whatever it takes" orientation, then it comes as no surprise that they would seek out tactics that involve extreme forms of reward and punishment.

Driven by a need for closure, some interrogators proceed to form quick and intuitive judgments about subjects, often in the absence of any extrinsic evidence. Research has shown that professional interrogators - trained, for example, in the Reid technique - tend to be overconfident in their ability to distinguish between truth and deception based on behavioral cues, despite chance-to-modest levels of accuracy (e.g., Kassin \& Fong, 1999; Vrij, Mann, \& Fisher, 2006). The reason for the inefficacy of training and experience is clear: By focusing on "behavioral symptoms of anxiety," accusatorial techniques merely formalize the "folk wisdom" that lay people already use with little success (Masip, Barba, \& Herrero, 2012; Masip, Herrero, Garrido, \& Barba, 2011).

Lacking an ability to make judgments of truth and deception at high levels of accuracy, the investigator who confidently identifies an interviewee for interrogation 
sets the stage for a process that is by definition guilt-presumptive, where success is measured by the interviewer's ability to secure a confession. The presumption of guilt that accompanies the start of interrogation thus provides fertile ground for the operation of confirmation biases. In a study that demonstrates the point, Kassin, Goldstein, and Savitsky (2003) had some participants - but not others - commit a mock theft, after which all were questioned by lay interrogators who were led to presume guilt or innocence. Results showed that interrogators who presumed guilt asked more incriminating questions, conducted more coercive interrogations, and tried harder to get the interviewee to confess. In turn, this more aggressive style made the interviewees sound defensive and led independent observers to infer guilt even when they were innocent. As applied to the question of why interrogators persist in their use of harsh tactics that are not demonstrably effective, this study suggests that the presumption of guilt can provide an illusion of support for the deception detection judgment previously made. Indeed, follow-up research has confirmed this counterproductive chain of events in suspect interviews (Hill, Memon, \& McGeorge, 2008; Narchet et al., 2011).

One might argue that investigators are aware of the guilt-presumptive process they bring to an interrogation and the influence they have over their subjects. If this were true, the self-insight would enable interrogators to mentally correct for the role they play in causing a subject to become anxious and, hence, to appear deceptive; and even at times to induce a subject to capitulate into giving a partial confession (Peer, Acquisti, \& Shalvi, 2014), a full confession (Kassin, 1997; Kassin \& Gudjonsson, 2004), a witness or alibi statement that implicates others (Loney \& Cutler, 2015; Moore, Cutler, \& Shulman, 2014; Wright, Nash, \& Wade, 2015), or other kinds of intelligence (Evans et al., 2014; Redlich, Kelly, \& Miller, 2014). However, research 
in other contexts indicates that people do not sufficiently account for the influence they exert over others. In an early demonstration of the fundamental attribution error, Jones and Harris (1967) found that people infer a student's attitude from the position he or she espouses in an essay, even when that student was assigned to argue for that particular position. Indicating how unaware people can be to a "self-generated reality," Gilbert and Jones (1986) found that participants continued to infer a speaker's attitude from the position taken in a speech even when they were the ones who had assigned the position the speaker was to take.

Across numerous domains as well, it is now clear that people underestimate the extent to which they condition the behavior of others. For example, one set of studies has shown that people do not recognize the influence they have over others' compliance when making prosocial requests such as the request for a charitable contribution (Bohns et al., 2011; Flynn \& Lake, 2008). Another set of studies has shown that people underestimate the influence they have on the unethical behavior of others - such as telling a white lie or getting vandalizing a book - that they had personally instigated (Bohns, Roghanizad, \& Xu, 2014). In short, there is no reason to believe that investigators are reliably or routinely aware without appropriate training of the ways in which their own conduct can shape the behavior and statements of the subjects they interrogate.

As an empirical matter, it remains to be seen whether the retribution motive that influences lay perceptions and policy makers of torture (discussed above) plays a similar role in motivating professional interrogators. Given the persuasive power of confession evidence, it stands to reason that the value of enhanced interrogation is perceived as "confirmed" when it produces a confession. But what about the tortured subject who resists efforts to "break" him or her and does not confess? In a laboratory 
experiment, Gray and Wegner (2010) examined how participants evaluated the guilt of a female confederate accused of cheating. In the experiment, some participants had met the woman while others had not; in addition, in some conditions the woman gave the impression of suffering while being interrogated in a staged session that participants heard in an audio recording and in others she did not. Among "distant" participants who had not met the confederate, her refusal to confess despite suffering was perceived as evidence of her innocence. Yet among "close" participants who had met the confederate, her suffering led them to infer guilt. Either to relieve the discomfort aroused by cognitive dissonance or out of the belief in a just world, participants in the close condition justified the confederate's pain by perceiving her to be guilty. Gray and Wegner note that these divergent effects help to explain, at least in part, the debate over the efficacy of 'enhanced interrogation'. To the distant public, the tortured subject appears innocent, and the process unacceptable. To interrogators, however, torture can become a self-justifying system, with subjects who suffer appearing guilty and therefore deserving of the pain being inflicted.

\section{Future research}

Future research into interrogation methods (now termed investigative interviewing methods in a growing number of countries) should continue to focus on methods for fostering cooperation as opposed to forcing compliance during interrogations. Future research could more firmly establish the "diagnostic value" of rapport-based approaches - that is, the enhanced likelihood that rapport-based methods would elicit true rather than false information (Meissner et al., 2010) - by continuing to assess their influence on guilty and innocent individuals (Meissner et al., 2015; Vallano \& Schreiber Compo, 2015). These methods should be consistent with applicable law, adherent with international standards for human rights, and 
should be tested in both laboratory and operational contexts. This is in alignment with an interim United Nations (2016) report, which also advocates for the development of such methods and the establishment of a universal protocol for investigative interviewing.

Most research studies on the effect of arousal examine witnesses viewing highly arousing (vs. neutral) events (see Deffenbacher, Bornstein, Penrod, \& McGorty, 2004, for a meta-analysis). The research informs us about how well, or poorly, people encode such extreme events. If we are concerned about the effects of "harsh interrogation," however, the research needs to manipulate arousal at the time of retrieval, not at the time of encoding. Presumably, when operatives first learn about dangerous or terrorist missions, they are relatively calm—or at least not in a state of panic. Extremely high levels of arousal occur later, perhaps while enacting the mission, and certainly while being interrogated. Without pinpointing the effects of arousal at retrieval, it is difficult to know what the effects will be and so we are forced to (a) examine the effects of high arousal on other cognitive processes (e.g., working memory) and then extrapolate to what should happen specifically at retrieval, or (b) argue logically how each component of an interrogation is likely to be affected by high arousal. Clearly, we would be on firmer ground if we had more direct evidence of the effect of arousal at retrieval. Given the ethical restraints that most academic researchers work under, it is difficult to imagine how we might create such a higharousal set of retrieval conditions. By comparison, it is easier to create high-arousal encoding conditions, as in waiting to receive an injection (Maass \& Kohnken, 1989) or participating in realistic, but simulated, crimes (e.g., Hope, Lewinski, Dixon, Blocksidge, \& Gabbert, 2012), or even memory for haunted house experiences (Valentine \& Mesout, 2009). The best opportunity we have to create such high- 
arousal interview conditions, we suspect, is to work in concert with the military or national security agencies, which provide training exercises for members who might be captured and interrogated by the enemy (see Morgan et al., 2004, 2006, 2013). On this note, we also encourage closer cooperation between research psychologists and such military-security agencies to design research studies that will provide us with more direct evidence of the effect of high arousal during interrogations (see Evans et al., 2010).

Standard deception experiments are carried out under specific circumstances. Typically, truth tellers and liars are interviewed just once and this happens immediately after experiencing an event, with the event being meaningful (or made meaningful) in some way to both truth tellers and liars (Vrij, 2008). In terms of instructions given to truth tellers and liars, they are often encouraged to be fully cooperative and to either tell the entire truth (truth tellers) or to be deceptive in most part of their statement (liars). This context may not reflect all real-life situations involving deception. For instance, sometimes individuals are interviewed after a delay and they may be interviewed multiple times. Also, the incident of interest may not have been important for truth tellers and therefore may not have attracted their full attention. Finally, the interviewees may not be fully cooperative, so that truth tellers could include minor lies in their statements, and liars' statements may be in substantial parts true (embedded lies, Leins, Fisher, \& Ross, 2013).

Research should address these alternative circumstances. If truth tellers and liars are interviewed after a delay, truth tellers may sound more like liars than when they are interviewed without a delay, because truth tellers show a memory decline whereas liars display a stability bias, that is, a failure to accurately calibrate their verbal output to take account of well-established patterns of forgetting over delay (Harvey, Vrij, 
Hope, Mann, \& Leal, 2017). Moreover, truth tellers may begin to sound more like liars if the event they discuss was only incidentally encoded versus intentionally encoded (Harvey, Vrij, Leal, Hope, \& Mann, 2017).

The few studies examining multiple interviews have shown that differences between truth tellers and liars in consistency are modest at best. When differences exist, liars appear to be more consistent than truth tellers, which disputes the stereotypical belief that liars are more inconsistent than truth tellers (Vredeveldt, van Koppen, \& Granhag, 2014). However, this finding is in line with the repeat versus reconstruct hypothesis (Granhag \& Strömwall, 1999, 2000). Liars need to keep track of their lies and try to repeat what they have said before, whereas truth tellers rely on their memory of the event. The latter leads to changes because memory is a reconstructive process (Fisher, Vrij, \& Leins, 2013). Liars' consistency depends on the interview style. For example, if liars become aware after an initial statement that investigators possess a certain piece of evidence, they may change their subsequent statement so that they can try to 'explain away' this piece of evidence (see the SUE approach discussed above, Granhag \& Hartwig, 2015).

Future research could also examine how the use of an interpreter affects the elicitation of (non)verbal cues to deceit (see Ewens et al., 2014, 2016a, b, c) and the ability to detect deceit.

Finally, with respect to beliefs about torture, research could focus on the questions how many laypersons, policy makers and interrogators support the use of torture and why they do or do not support it. These are important questions, because the use of torture is only likely to be abandoned if these groups of people largely reject it.

\section{Conclusions}


Psychological theory and research show that harsh interrogation methods (including torture and accusatorial methods) are ineffective as a strategy for eliciting accurate and complete information from an interviewee for several reasons. First, they are likely to increase resistance by the interviewee and not decrease it. Second, the threatening and adversarial nature of harsh interrogation is often inimical to the goals of fostering efficient cognition. As a result, such methods reduce the likelihood that interviewees will provide reports that are extensive, detailed, and accurate. Third, harsh interrogation methods make lie detection - a challenging undertaking - even more difficult. To effectively identify verbal cues to deceit (the most reliable method of lie detection), interviewees must offer extensive narratives, something that rarely occurs in harsh interrogations. Evidence is accumulating for the effectiveness of information-gathering approaches as an effective alternative to harsh interrogations. Such methods promote cooperation, enhance recall of relevant and reliable information, and facilitate assessments of credibility. We hope this article informs the ongoing debate worldwide over interrogation doctrines, contributes to a fruitful collaboration between practitioners and researchers, and leads to the systematic introduction of evidence-based interrogation techniques into training and practice.

\section{Acknowledgement}

A portion of the research conducted by Vrij, Meissner, Fisher, Morgan, and Kleinman has been supported by the U.S. High-Value Detainee Interrogation Group. 


\section{References}

Aamodt, M. G., \& Custer, H. (2006). Who can best catch a liar? A meta-analysis of individual differences in detecting deception. The Forensic Examiner, 15, 611.

Abbe, A., \& Brandon, S. E. (2013). The role of rapport in investigative interviewing: A Review. Journal of Investigative Psychology and Offender Profiling, 10, 237-249. doi:10.1002/jip.1386

Abbe A, Brandon SE. (2014). Building and maintaining rapport in investigative interviews. Police Practice \& Research, 15, 207-220. doi:10.1080/175- 1305- 080189- 1986

Alexander, M. \& Bruning, J. R. (2008). How to Break a Terrorist: The U.S. Interrogators Who Used Brains, Not Brutality, to Take Down the Deadliest Man in Iraq. New York: Free Press.

Alison, L. J., Alison, E., Noone, G., Elntib, S., \& Christiansen, P. (2013). Why tough tactics fail and rapport gets results: Observing Rapport-Based Interpersonal Techniques (ORBIT) to generate useful information from terrorists. Psychology, Public Policy, and Law, 19, 411-431. doi:10.1037/a0034564

Alison, L., Alison, E., Noone, G., Elntib, S., Waring, S., \& Christiansen, P. (2014a). The efficacy of rapport-based techniques for minimizing counter-interrogation tactics amongst a field sample of terrorists. Psychology, Public Policy, and Law, 20, 420-430. doi:10.1037/law0000021

Alison, L., Alison, E., Noone, G., Elntib, S., Waring, S., \& Christiansen, P. (2014b). Whatever you say, say nothing: Individual differences in counter interrogation tactics amongst a field sample of right wing, AQ inspired and paramilitary 
terrorists. Personality and Individual Differences, 68, 170-175.

doi:10.1016/j.paid.2014.04.031

Andrews, G. (2001). MKULTRA: The CIA's Top Secret Program in Human Experimentation and Behavior Modification. Healthnet Press.

Arntz, A., \& Claassens, L. (2004). The meaning of pain influences its experienced intensity. Pain, 109, 20-25. doi:10.1016/j.pain.2003.12.030

Arrigo, J. M. (2004). A utilitarian argument against torture interrogation of terrorists. Science and Engineering Ethics, 10, 543-572. doi:10.1007/s11948-004-0011-y

Balko, R. (March 10, 2017). Big changes may be coming to police interrogations. The Washington Post. Retrieved from https://www.washingtonpost.com/news/thewatch/wp/2017/03/10/big-changes-may-be-coming-to-police-interrogations/.

Bell, J. (2008). Behind this mortal bone: The (in)effectiveness of torture. Indiana Law Journal, 83, 339-361.

Bernieri, F. J., \& Gillis, J. S. (2001). Judging rapport: Employing Brunswik's lens model to study interpersonal sensitivity. In J. A. Hall \& F. J. Bernieri (Eds.), Interpersonal sensitivity: Theory and measurement (pp. 67-88). Mahwah, NJ: Erlbaum.

Biderman, A. D. (1960). Social-psychological needs and" involuntary" behavior as illustrated by compliance in interrogation. Sociometry, 23, 120-147. doi.org/10.2307/2785678

Birtchnell, J. (2002). Psychotherapy and the interpersonal octagon. Psychology and Psychotherapy: Theory, Research and Practice, 75, 349-363. doi/10.1348/147608302320365235/

Bohns, V. K., Handgraaf, M. J. J., Sun, J., Aaldering, H., Mao, C., \& Logg, J. (2011). Are social prediction errors universal? Predicting compliance with a direct 
request across cultures. Journal of Experimental Social Psychology, 47, 676680. doi:10.1016/j.jesp.2011.01.001

Bohns, V. K., Roghanizad, M. M., \& Xu, A. Z. (2014). Underestimating our influence over others' unethical behavior and decisions. Personality and Social Psychology Bulletin, 40, 348-362. doi: 10.1177/0146167213511825

Bond, C. F., \& DePaulo, B. M. (2006). Accuracy of deception judgements. Personality and Social Psychology Review, 10, 214-234. doi:10.1207/s15327957pspr1003_2

Bond, C. F., \& Fahey, W. E. (1987). False suspicion and the misperception of deceit. British Journal of Social Psychology, 26, 41-46. doi:10.1111/j.20448309.1987.tb00759.x

Borum, R., Gelles, M., \& Kleinman, S. (2009). Interview and interrogation: A perspective and update from the USA. In R. Milne, S. Savage, \& T. Williamson (Eds.) International developments in investigative interviewing (pp. 111-128). Cullomtpon, Devon, England: Willan Publishing.

Brown v. Mississippi, 297 U.S. 278 (1936).

Brehm, J.W. (1966). A theory of psychological reactance. New York: Academic Press British Psychological Society. (2016). News - United Nations may recommend PEACE approach. The Psychologist, 29, 897.

Bull, R., \& Milne, B. (2004a). Attempts to improve the police interviewing of suspects. In D. Lassiter (Ed.), Interrogations, confessions, and entrapment (pp. 181-196). New York: Kluwer Academic/Plenum Publishers.

Bull, R., \& Milne, R. (2004b). Investigative interviewing: Psychology and practice. Chichester: Wiley, 55-72. 
Burke, B. L., Martens, A., \& Faucher, E. H. (2010). Two decades of terror management theory: A meta-analysis of mortality salience research. Personality and Social Psychology Review, 14, 155-195. doi: $10.1177 / 1088868309352321$

Carlsmith, K. M. (2006). The roles of retribution and utility in determining punishment. Journal of Experimental Social Psychology, 42, 437-451. doi:10.1016/j.jesp.2005.06.007

Carlsmith, K. M., \& Darley, J. M. (2008). Psychological aspects of retributive justice. Advances in Experimental Social Psychology, 40, 193-236. doi:10.1016/S0065-2601(07)00004-4

Carlsmith, K. M., \& Sood, A. M. (2009). The fine line between interrogation and retribution. Journal of Experimental Social Psychology, 45, 191-196. doi:10.1016/j.jesp.2008.08.025

Carlson, L. H. (2002). Remembered prisoners of a forgotten war. New York: St. Martin's Press.

Christ, S., E., Van Essen, D. C. Watson, J. M., Brubaker, L. E., \& McDermott, K. B. (2009). The Contributions of prefrontal cortex and executive control to deception: Evidence from activation likelihood estimate meta-analyses. Cerebral Cortex, 19, 1557-1566. doi:10.1093/cercor/bhn189

Chulov, M., \& Pidd, H. (2011). Curveball: How US was duped by Iraqi fantasis looking to topple Saddam. The Guardian, Tuesday 15 February, https://www.theguardian.com/world/2011/feb/15/curveball-iraqi-fantasist-ciasaddamhttps://www.theguardian.com/world/2011/feb/15/curveball$\underline{\text { iraqi-fantasist-cia-saddam }}$ 
Cialdini R. B. (2006). Influence: The Psychology of Persuasion. New York: HarperCollins.

Cobain, I. (2005). The secrets of the London Cage. The Guardian, 12, 8.

Cohen, J. (1988). Statistical power analysis for the behavioral sciences (2nd ed.). Hillsdale, NJ: Erlbaum.

Collins, R., Lincoln, R., \& Frank, M. G. (2002). The effects of rapport in forensic interviewing. Psychiatry, Psychology \& Law, 91, 69-78. doi:10.1375/pplt.2002.9

Costanzo, M. A., \& Gerrity, E. (2009). The effects and effectiveness of using torture as an interrogation device: Using research to inform the policy debate. Social Issues and Policy Review, 3, 179-210. doi:10.1111/j.1751-2409.2009.01014.x

Davis, D., \& Leo, R. A. (2012). Interrogation-related regulatory decline: Ego-depletion, failures of self-regulation and decision to confess. Psychology, Public Policy, \& Law, 18, 673-704. doi:10.1037/a0027367

Davis, D., Soref, A., Villalobos, J. G., \& Mikulincer, M. (2016). Priming states of mind can affect disclosure of threatening self-information: Effects of selfaffirmation, mortality salience, and attachment orientations. Law and Human Behavior, 40, 351-361. doi:10.1037/lhb0000184

Debey, E., Verschuere, B., \& Crombez, G. (2012). Lying and executive control: An experimental investigation using ego depletion and goal neglect. Acta Psychologica, 140, 133-141. DOI: 10.1016/j.actpsy.2012.03.004

Department of Defense. (2012, Oct. 11). DoD Intelligence Interrogations, Detainee Debriefings, and Tactical Questioning (DoD Directive 3115.09). Washington, DC: Undersecretary of Defense for Intelligence. 
Deffenbacher, K. A., Bornstein, B. H., Penrod, S.D., \& McGorty, E. K. (2004). A meta-analytic review of the effects of high stress on eyewitness memory. Law \& Human Behavior, 28, 687-706. doi:10.1007/s10979-004-0565-x

DePaulo, B. M., \& Kirkendol, S. E. (1989). The motivational impairment effect in the communication of deception. In J. C. Yuille (Ed.), Credibility assessment (pp. 51-70). Dordrecht, the Netherlands: Kluwer.

DePaulo, B. M., Lindsay, J. L., Malone, B. E., Muhlenbruck, L., Charlton, K., \& Cooper, H. (2003). Cues to deception. Psychological Bulletin, 129, 74-118. DOI: $10.1037 / 0033-2909.129 .1 .74$

Dijksterhuis, A., van Knippenberg, A., Kruglanski, A. W., \& Schaper, C. (1996). Motivated social cognition: Need for closure effects on memory and judgment. Journal of Experimental Social Psychology, 32, 254-270. doi: 10.1006/jesp.1996.0012

Ekman, P. (1985). Telling lies: Clues to deceit in the marketplace, politics and marriage. New York: W. W. Norton. (Reprinted in 1992, 2001 and 2009).

Evans, J.R., \& Fisher, R. P. (2011). Eyewitness memory: Balancing the accuracy, precision, and quantity of information. Applied Cognitive Psychology, 25, 501-508. doi:10.1002/acp.1722

Evans, J. R., Houston, K. A., Meissner, C. A., Ross, A. B., Labianca, J. R., Woestehoff, S. A., \& Kleinman, S. M. (2014). An empirical evaluation of intelligence-gathering interrogation techniques from the United States Army field manual. Applied Cognitive Psychology, 28, 867-875. doi:10.1002/acp.3065

Evans, J. R., Meissner, C. A., Ross, A. B., Houston, K. A., Russano, M. B., \& Horgan, J. A. (2013a). Obtaining guilty knowledge in human intelligence 
interrogations: Comparing accusatorial and information-gathering approaches with a novel experimental paradigm. Journal of Applied Research in Memory and Cognition, 2, 83-88. doi:10.1016/j.jarmac.2013.03.002

Evans, J. R., Meissner, C. A., Ross, A. B., Houston, K. A., Russano, M. B., \& Kleinman, S. M. (2010). Criminal versus HUMINT Interrogations: The important of psychological science to improving interrogative practice. Journal of Psychiatry and Law, 38, 215-249.

doi: $10.1177 / 009318531003800110$

Evans, J. R., Michael, S. W., Meissner, C. A., \& Brandon, S. E. (2013b). Validating a new assessment method for deception detection: Introducing a Psychologically Based Credibility Assessment Tool. Journal of Applied Research in Memory and Cognition, 2, 33-41. doi:10.1016/j/jarmac.2013.02.002.

Ewens, S., Vrij, A., Leal, S., Mann, S., Jo, E., \& Fisher, R. P. (2014, published online). The effect of interpreters on eliciting information, cues to deceit and rapport. Legal and Criminological Psychology. doi: 10.1111/lcrp.12067 IN EWENS STUDY 2.

Ewens, S., Vrij, A., Leal, S., Mann, S., Jo, E., \& Houston, K. (2016a). The effect of the presence and seating position of an interpreter on eliciting information and cues to deceit. Psychology, Crime, \& Law, 23, 180-200. doi:10.1080/1068316X.2016.1239100

Ewens, S., Vrij, A., Leal, S., Mann, S., Jo, E., Shaboltas, A., Ivanova, M., Granskaya, J., \& Houston, K. (2016b). Using the model statement to elicit information and cues to deceit from native speakers, non-native speakers and those talking 
through an interpreter. Applied Cognitive Psychology, 30, 854-862. doi:10.1002/acp.3270

Ewens, S., Vrij, A., Mann, S., \& Leal, S. (2016c). Using the reverse order technique with non-native speakers or through an interpreter. Applied Cognitive Psychology, 30, 242-249. doi:10.1002/acp.3196

Fallon, M. (2015). Collaboration between practice and science will enhance interrogations. Applied Cognitive Psychology, 28, 949-950. doi:10.1002/acp.3091

Farber, I. E., Harlow, H. \& West, L. (1957). Brainwashing, conditioning, and DDD (Debility, Dependency, and Dread). Sociometry, 20, 271-285. doi.org/10.2307/2785980

Fein, P. (1994). We Have Ways: The Law and Morality of the Interrogation of Prisoners of War. Unpublished Ph.D. Dissertation. Washington, DC: Georgetown University.

Fein, R. A., Lehner, P., \& Vossekuil, B. (2006). Educing information: Interrogation science and art. Washington, DC: National Defense Intelligence College.

Fenn, K. M., Gallo, D. A., Margoliash, D., Roediger, H. L., \& Nusbaum, H. C. (2009). Reduced false memory after sleep. Learning \& Memory, 16, 509-513. doi:10.1101/lm.1500808

Festinger, L. (1954). A theory of social comparison processes. Human relations, 7(2), 117-140. doi: 10.1177/001872675400700202

Fischer, A., Oswald, M. E., \& Seiler, S. (2013). Terrorists among us: Effects of a suspect's group membership, terrorist past, and knowledge on lay persons' interrogation severity recommendations. Swiss Journal of Psychology, 72, 1323. doi:10.1024/1421- 0185/a000094 
Fisher, R. P. \& Geiselman, R. E. (1992) Memory-enhancing techniques in investigative interviewing: The cognitive interview. Springfield, IL: C.C. Thomas.

Fisher, R. P., Schreiber Compo, N., Rivard, J., \& Hirn, D. (2014). Interviewing Witnesses. In T. Perfect \& S. Lindsay (Eds.), The SAGE Handbook of Applied Memory (pp. 559-578). Los Angeles: SAGE press.

Fisher, R. P., Vrij, A., \& Leins, D. A. (2013). Does testimonial inconsistency indicate memory inaccuracy and deception? Beliefs, empirical research and theory. In B. S. Cooper, D. Griesel, \& M. Ternes (Eds.) Applied issues in investigative interviewing, eyewitness memory, and credibility assessment (pp. 173190). Springer: New York.

Flynn, F. J., \& Lake, V. K. B. (2008). If you need help, just ask: Underestimating compliance with direct requests for help. Journal of Personality and Social Psychology, 95, 128-143. doi:10.1037/0022-3514.95

Frenda, S. J., Nichols, R. M., \& Loftus, E. F. (2011). Current issues and advances in misinformation research. Current Directions in Psychological Science, 20, 2023. doi:10.1177/0963721410396620

Gatchel, R. J., Peng, Y. B., Peters, M. L., Fuchs, P. N., \& Turk, D. C. (2007). The biopsychosocial approach to chronic pain: scientific advances and future directions. Psychological Bulletin, 133, 581-624. doi:10.1037/00332909.133.4.581

Geiselman, R. E. (2012). The cognitive interview for suspects (CIS). American College of Forensic Psychology, 30, 1-16. 
Gilbert, D. T., \& Jones, E. E. (1986). Perceiver-induced constraint: Interpretations of self-generated reality. Journal of Personality and Social Psychology, 50, 269280. doi:10.1037/0022-3514.50.2.269

Glenberg, A. M., Schroeder, J. L., \& Robertson, D. A. (1998). Averting the gaze disengages the environment and facilitates remembering. Memory \& Cognition, 26, 651-658. doi:10.3758/BF03211385

Goldsmith, M., Koriat, A., \& Weinberg-Eliezer, A. (2002). Strategic regulation of grain size memory reporting. Journal of Experimental Psychology: General, 131, 73-95. doi:10.1016/0273-2297(90)90003- M

Goodman-Delahunty J, Howes LM. 2014. Social persuasion to develop rapport in high-stakes interviews: Qualitative analyses of Asian-Pacific practices. Policing and Society: An International Journal of Research and Policy, 1-23. doi:10.1080/10439463.2014.942848

Goodman-Delahunty, J., Martschuk, N., \& Dhami, M. K. (2014). Interviewing high value detainees: Securing cooperation and disclosures. Applied Cognitive Psychology, 28, 883-897. doi:10.1002/acp.3087

Gordon, N. J. \& Fleisher, W.L. (2011). Effective interviewing and interrogation techniques. Academic Press: Burlington, MA, USA.

Granhag, P.A. \& Hartwig, M. (2008). A new theoretical perspective on deception detection: On the psychology of instrumental mind-reading. Psychology, Crime \& Law, 14, 189-200. doi:10.1080/10683160701645181

Granhag, P. A., \& Hartwig, M. (2015). The Strategic Use of Evidence (SUE) technique: A conceptual overview. In P. A. Granhag, A. Vrij, \& B. Verschuere (Eds.), Deception detection: Current challenges and new approaches (pp. 231-251). Chichester, England: Wiley. 
Granhag, P. A., Oleszkiewicz, S., Strömwall, L. A., \& Kleinman, S. M. (2015).

Eliciting intelligence with the Scharff technique: Interviewing more and less cooperative and capable sources. Psychology, Public Policy, and Law, 21, 100-110. doi:10.1037/law.0000030

Granhag, P. A., \& Strömwall, L. A. (1999). Repeated interrogations-Stretching the deception detection paradigm. Expert Evidence, 7, 163-174. doi:10.1023/a:1008993326434

Granhag, P. A., \& Strömwall, L. A. (2000a). Deception detection: Examining the consistency heuristic. In C. M. Breur, M. M. Kommer, J. F. Nijboer \& J. M. Reintjes (Eds.), New trends in criminal investigation and evidence (Vol. 2, pp. 309-321). Antwerpen: Intresentia.

Gray, K., \& Wegner, D. M. (2010). Torture and judgments of guilt. Journal of Experimental Social Psychology, 46, 233-235. doi:10.1016/j.jesp.2009.10.003

Gudjonsson, G.H., \& MacKeith, J.A.C. (1982). False confessions: Psychological effects of interrogation: A discussion paper. In A. Trankell (Ed.), Reconstructing the past: The role of psychologists in criminal trials (pp. 253 269). Deventer, the Netherlands: Kluwer.

Hadjistavropoulos, T., \& Craig, K. D. (Eds.). (2004). Pain: Psychological perspectives. Mahwah, NJ: Lawrence Erlbaum Associates.

Häkkänen, H., Ask, K., Kebbell, M., Alison, L., \& Granhag, P. A. (2009). Police officers' views of effective interview tactics with suspects: The effects of weight of case evidence and discomfort with ambiguity. Applied Cognitive Psychology, 23, 468-481. doi:10.1002/acp.1491

Harvey, A., Vrij, A., Hope, L., Mann, S., \& Leal, S. (2017). A stability effect amongst deceivers. Manuscript under review. 
Harvey, A., Vrij, A., Leal, S., Hope, L., \& Mann, S. (2017). Deception and decay: Verbal lie detection as a function of delay and encoding quality. Manuscript under review.

Harvey, A., Vrij, A., Nahari, G,. \& Ludwig, K. (In press). Applying the Verifiability Approach to insurance claims settings: Exploring the effect of the information protocol. Legal and Criminological Psychology. doi:10.1111/lcrp.12092

Hauch, V., Sporer, S. L., Michael, S. W., \& Meissner, C. A. (2014). Does training improve the detection of deception? A meta-analysis. Communication Research published online 25 May 2014 doi:10.1177/0093650214534974

Hartwig, M., \& Bond, C. F. (2011). Why do lie-catchers fail? A lens model metaanalysis of human lie judgments. Psychological Bulletin, 137, 643-659. doi:10.1037/a0023589

Hartwig, M., \& Bond, C. F. (2014). Lie detection from multiple cues: A metaanalysis. Applied Cognitive Psychology, 28, 661-667. doi:10.1002/acp.3052

Hartwig, M., Granhag, P. A., \& Luke, T. (2014). Strategic use of evidence during investigative interviews: The state of the science. In: Raskin, D.C., Honts, C.R., Kircher, J.C. (Eds.), Credibility Assessment: Scientific Research and Applications (pp. 1-36). Oxford, UK: Academic Press.

Hartwig, M., Granhag, P. A., \& Strömwall, L. (2007). Guilty and innocent suspects' strategies during police interrogations. Psychology, Crime, \& Law, 13, 213227. doi:10.1080/10683160600750264

Hartwig, M., Granhag, P. A., Strömwall, L, \& Doering, N. (2010). Impression and information management: On the strategic self-regulation of innocent and guilty suspects. The Open Criminology Journal, 3, 10-16. doi:10.2174/1874917801003010010 
Hartwig, M., Meissner, C. A., \& Semel, M. D. (2014). Human intelligence interviewing and interrogation: Assessing the challenges of developing an ethical, evidence-based approach. In R. Bull (Ed.), Investigative interviewing. New York, NY: Springer.

Hill, C., Memon, A., \& McGeorge, P. (2008). The role of confirmation bias in suspect interviews: A systematic evaluation. Legal \& Criminological Psychology, 13, 357-371. doi:10.1348/135532507X238682

Hirschberger, G., \& Ein-Dor, T. (2006). Defenders of a lost cause: Terror management and violent resistance to the disengagement plan. Personality and Social Psychology Bulletin, 32, 761-769. doi:10.1177/0146167206286628

Holmberg, U., \& Christianson, S. A. (2002). Murderers' and sexual offenders' experiences of police interviews and their inclination to admit or deny crimes. Behavioral Sciences and the Law, 20, 31-45. doi:10.1002/bsl.470

Hope, L., Lewinski, W., Dixon, J., Blocksidge, D., \& Gabbert F. (2012). Witnesses in action: the effect of physical exertion on recall and recognition. Psychological Science, 23, 386-390. doi:10.1177/0956797611431463

Horgan, A. J., Russano, M. B., Meissner, C. A., \& Evans, J. R. (2012). Minimization and maximization techniques: Assessing the perceived consequences of confessing and confession diagnosticity. Psychology, Crime, and Law, 18, 6578. doi:10.1080/1068316X.2011.561801

Horvath, F., Jayne, B., \& Buckley, J. (1994). Differentiation of truthful and deceptive criminal suspects in behavioral analysis interviews. Journal of Forensic Sciences, 39, 793-807. 
Hoscheidt, S., Dongaonkar, B., Payne, J., \& Nadel, L. (2013). Emotion, stress, and memory. In D. Reisburg's (Ed.), Oxford Handbook of Cognitive Psychology, 557-570. New York: Oxford University Press.

Houck, S. C., \& Conway, L. G., III. (2013). What people think about torture: Torture is inherently bad ... unless it can save someone I love. Journal of Applied Security Research, 8, 429 - 454. doi:10 .1080/19361610.2013.825750

Houck, S. C., \& Conway, L. G. III. (2015) Ethically investigating torture efficacy: A new methodology to test the influence of physical pain on decision-making processes in experimental interrogation scenarios. Journal of Applied Security Research, 10, 510-524. doi:10.1080/19361610.2015.1069636

Houck, S. C., Conway, L. G., III, \& Repke, M. A. (2014). Personal closeness and perceived torture efficacy: If torture will save someone I'm close to, then it must work. Peace and Conflict: Journal of Peace Psychology, 20, 590-592. doi.org/10.1037/pac0000058

Houston, P., Floyd, M., \& Carnicero, S. (2012). Spy the lie. New York: St. Martin's Press.

Inbau, F. E., \& Reid, J. E. (1962). Criminal interrogation and confessions. Baltimore: Williams \& Wilkins.

Inbau, F. E., Reid, J. E., Buckley, J. P., \& Jayne, B. C. (2013). Criminal interrogation and confessions, $5^{\text {th }}$ edition. Burlington, MA: Jones \& Bartlett Learning.

Irving, B. (1980). Police interrogation. A case study of current practice. Research Studies No. 2. London: HMSO

Irving, B. \& Hilgendorf, L. (1980). Police interrogation: The psychological approach. Research Studies No. 1. London: HMSO. 
Johnson, M. K. (2006). Memory and reality. American Psychologist, 61, 760-771. doi:10.1037/0003-066X.61.8.760

Johnson, M. K., Hashtroudi, S., \& Lindsay, D. (1993). Source monitoring. Psychological Bulletin, 114, 3-28. doi:10.1037/00332909

Johnston, W. A., Greenberg, S. N., Fisher, R. P., \& Martin, D. W. (1970). Divided attention: A vehicle for monitoring memory processes. Journal of Experimental Psychology, 83, 164-171. doi:10.1037/ h0028554

Kassin, S.M. (1997). The psychology of confession evidence. American Psychologist, 52, 221-233. doi:10.1037/0003-066x.52.3.221

Kassin, S. M. (2005). On the psychology of confessions: Does innocence put innocents at risk? American Psychologist, 60, 215-228. doi:10.1037/0003066X.60.3.215

Kassin, S. M. (2006). A critical appraisal of modern police interrogations. In T. Williamson (Ed.), Investigative interviewing: Rights, research, regulation (pp. 207-228). Devon, UK: Willan Publishing.

Kassin, S. M. (2015). The social psychology of false confessions. Social Issues and Policy Review 9, 24-49. doi:10.1207/

Kassin, S. M., Drizin, S. A., Grisso, T., Gudjonsson, G. H., Leo, R. A., \& Redlich, A. D. (2010). Police-induced confessions: Risk factors and recommendations. Law and Human Behavior, 34, 3-38. doi:10.1007/s10979-009-9188-6

Kassin, S. M., \& Fong, C. T. (1999). “I'm innocent!”: Effects of training on judgments of truth and deception in the interrogation room. Law and Human Behavior, 23, 499-516. doi:10.1023/A:1022330011811 
Kassin, S. M., Goldstein, C. J., \& Savitsky, K. (2003). Behavioral confirmation in the interrogation room: On the dangers of presuming guilt. Law and Human Behavior, 27, 187-203. doi:0147-7177/03/04000187/1

Kassin, S. M., \& Gudjonsson, G. H. (2004). The Psychology of confessions: A Review of the literature and issues. Psychological Science in the Public Interest, 5, 33-67. doi:10.1111/j.1529-1006.2004.00016.x

Kassin, S. M., \& Kiechel, K. L. (1996). The social psychology of false confessions: Compliance, internalization, and confabulation. Psychological Science, 7, 125-128. doi:1.1111/j.1467-928.1996.tb00344.x

Kassin, S. M., Leo, R. A., Meissner, C. A., Richman, K. D., Colwell, L. H., Leach, A. M., \& La Fon, D. (2007). Police interviewing and interrogation: A self-report survey of police practices and beliefs. Law and Human Behavior, 31, 381-400. doi:10.1007/s10979-006-9073

Kassin, S. M., Meissner, C. A., \& Norwick, R. J. (2005). "I'd know a false confession if I saw one": A comparative study of college students and police investigators. Law and Human Behavior, 29, 211-227. doi:10.1007/s10979005-2416-9

Kebbell, M., Alison, L., Hurren, E., \& Mazerolle, P. (2010). How do sex offenders think the police should interview to elicit confessions from sex offenders? Psychology, Crime \& Law, 16, 567-584.

Kelly, C. E. \& Meissner, C. A. (2015). Interrogation and investigative interviewing in the United States: Research and practice. In D. Walsh, G. E., Oxburgh, A. D. Redlich, \& T. Myklebust (Eds.), International developments and practices in investigative interviewing and interrogation (pp. 255-266). London: Routledge. 
Kelly, C. E., Redlich, A. D., \& Miller, J. C. (2015). Examining the meso-level domains of the interrogation taxonomy. Psychology, Public Policy, and Law, 21, 179-191. doi:10.1037/law0000034

Kelman H. C. (2006). Interests, relationships, identities: three central issues for individuals and groups in negotiating their social environment. Annual Review of Psychology, 57, 1-26. doi:10.1146/annurev. psych.57.102904.190156

Kieckhaefer, J. M., Vallano, J. P., \& Schreiber Compo, N. (2013). Examining the Positive Effects of Rapport Building: When and Why Does Rapport Building Benefit Adult Eyewitness Memory? Memory,1-14.

DOI:10.1080/09658211.2013.864313

Kleinman, S. M. (2006). KUBARK counterintelligence interrogation review: Observations of an interrogator. In R. A. Fein, P. Lehner, \& B. Vossekuil (Eds.), Educing information, Interrogation: Science and art, foundations for the future (pp. 95-140). Washington DC: National Military Intelligence College Press.

Knieps, M., Granhag, P. A., \& Vrij, A. (2013). Back to the future: Asking about mental images to discriminate between true and false intentions. The Journal of Psychology: Interdisciplinary and Applied, 147, 619-640.

Köhnken G., Thurer, C., \& Zorberbier, D. (1994). The cognitive interview: Are interviewers memories enhanced too? Applied Cognitive Psychology, 8, 13-24. doi:10.1002/acp.2350080103

Kolker, R. (May 24, 2016). A severed head, two cops, and the future of interrogation. Wired. Retrieved from https://www.wired.com/2016/05/how-to-interrogatesuspects/. 
Kruglanski, A. W. (2004). The psychology of closed mindedness. New York, NY: Psychology Press.

Kruglanski, A. W., \& Freund, T. (1983). The freezing and unfreezing of layinferences: Effects on impressional primacy, ethnic stereotyping and numerical anchoring. Journal of Experimental Social Psychology, 19, 448468. doi:10.1016/0022-1031(83)90022- 7

Kruglanski, A. W., Pierro, A., Mannetti, L., \& De Grada, E. (2006). Groups as epistemic providers: Need for closure and the unfolding of group-centrism. Psychological Review, 113, 84-100. doi:10.1037/0033-295X.113.1.84

Kruglanski, A. W., \& Webster, D. M. (1991). Group members' reactions to opinion deviates and conformists at varying degrees of proximity to decision deadline and of environmental noise. Journal of Personality and Social Psychology, 61, 212-225. doi:10.1037/0022-3514.61

Lassiter, G. D., \& Meissner, C. A. (Eds.) (2010). Police interrogations and false confessions: Current research, practice, and policy recommendations. Washington, DC: American Psychological Association.

Lawrence, H. (2017). 'Mind the gap': Exaggerating verbal differences between children's true and false reports using cognitive lie detection techniques. Unpublished Ph.D dissertation. Portsmouth, UK: University of Portsmouth.

Leal, S., Vrij, A., Warmelink, L., Vernham, Z., \& Fisher, R. (2015). You cannot hide your telephone lies: Providing a model statement as an aid to detect deception in insurance telephone calls. Legal and Criminological Psychology, 20, 129146. doi:10.1111/lcrp. 12017

Leary, T. F., \& Coffey, H. S. (1954). The prediction of interpersonal behavior in group psychotherapy. Group Psychotherapy, 7, 7-51. 
Leins, D., Fisher, R. P., \& Ross, S. J. (2013). Exploring liars' strategies for creating deceptive reports. Legal and Criminological Psychology, 18, 141-151. DOI: $10.1111 / \mathrm{j} .2044-8333.2011 .02041 . x$

Leo, R. A. (2008). Police interrogation and American justice. Cambridge, MA: Harvard University Press.

Liberman, P. (2014). War and torture as "just deserts." Public Opinion Quarterly, 78, 47-70. doi:10.1093/poq/nft081

Lieberman, H. R., Bathalon, G. P., Falco, C. M., Kramer, M., Morgan III, C. A., \& Niro, P. (2005). Severe decrements in cognition function and mood induced by sleep loss, heat, dehydration, and under-nutrition during simulated combat. Biological Psychiatry, 15, 57, 422-429. doi:10.1016/j.biopsych.2004.11.014

Loftus, E. F. (2011). Intelligence gathering post-9/11. American Psychologist, 66, 532-541. doi:10.1037/a0024614

Loney, D. M., \& Cutler, B. L. (2016). Coercive interrogation of eyewitnesses can produce false accusations. Journal of Police and Criminal Psychology, 31, 2936. doi:10.1007/s11896-015-9165-6

Lopez, N., Previc, F. H., Fischer, J., Heitz, R. P., \& Engle, R. W. (2012). Effects of sleep deprivation on cognitive performance by United States Air Force pilots. Journal of Applied Research in Memory and Cognition, 1, 27-33. doi:10.1016/j

Maass, A. \& Köhnken, G. (1989). Eyewitness identification: Simulating the "Weapon effect" (1989). Law \& Human Behavior, 13, 397-408. doi:10.1007/BF01056411

Madon, S., Guyll, M., Scherr, K. C., Greathouse, S., \& Wells, G. L. (2012). Temporal 
discounting: The differential effect of proximal and distal consequences on confession decisions. Law and Human Behavior, 36, 13-20. doi:10.1037/h0093962

Mann, S., Vrij, A., \& Bull, R. (2004). Detecting true lies: Police officers' ability to detect deceit. Journal of Applied Psychology, 89, 137-149. DOI: org/10.1037/00219010.89 .1 .137

Margulies, J. (2006, October 2). The more subtle kind of torment. The Washington Post.

Masip, J., Barba, A., \& Herrero, C. (2012). Behavioral Analysis Interview and common sense: A study with novice and experienced officers. Psychiatry, Psychology, and Law, 19, 21-34. doi:10.1080/13218719.2010.543402

Masip, J., Herrero, C., Garrido, E., \& Barba, A. (2011). Is the Behavior Analysis Interview just common sense? Applied Cognitive Psychology, 25, 593-604. doi:10.1002/acp.1728

Masip, J., Sporer, S., Garrido, E., \& Herrero, C. (2005). The detection of deception with the reality monitoring approach: A review of the empirical evidence. Psychology, Crime, \& Law, 11, 99-122. doi:10.1080/10683160410001726356

Mehrabian, A. (1971). Silent messages, $1^{\text {st }}$ edition. Belmont, CA: Wadsworth.

Meissner, C. A., \& Albrechtsen, J. S. (2007). Interrogation and torture. 2007 Yearbook of science \& technology (pp. 125-127), New York: McGraw-Hill.

Meissner, C. A., \& Kassin, S. M. (2002). 'He's guilty!': Investigator bias in judgments of truth and deception. Law and Human Behavior, 26, 469-480. doi:10.1023/A:1020278620751

Meissner, C. A., \& Kassin, S. M. (2004). "You're guilty, so just confess!” Cognitive and behavioural confirmation biases in the interrogation room. In D. Lassiter 
(Ed.), Interrogations, confessions, and entrapment (pp. 85-106). New York: Kluwer Academic/Plenum Publishers.

Meissner, C. A., Kelly, C. E., \& Woestehoff, S. A. (2015). Improving the effectiveness of suspect interrogations. Annual Review of Law and Social Sciences, 11, 211-233. doi:10.1146/annurev-lawsocsci-120814-121657

Meissner, C. A., Redlich, A. D., Michael, S. W., Evans, J. R., Camiletti, C. R., Bhatt, S., \& Brandon, S. (2014). Accusatorial and information-gathering interrogation methods and their effects on true and false confessions: A metaanalytic review. Journal of Experimental Criminology, 10, 459-486. doi:10.1007/s11292-014-9207-6

Meissner, C. A., Russano, M. B., \& Narchet, F. M. (2010). The importance of a laboratory science for improving the diagnostic value of confession evidence. In G. D. Lassiter \& C. Meissner's (Eds.), Police interrogations and false confessions: Current research, practice, and policy recommendations (pp. 111-126). Washington, DC: APA.

Memon, A., Holley, A., Wark, L., Bull, R., \& Köhnken, G. (1996). Reducing suggestibility in child witness interviews. Applied Cognitive Psychology, 10, 503-518. doi: 10.1002/(SIECI)1099-0720(199612)10:63.0.CO;2-R

Memon, A., Meissner, C, A., \& Fraser, J. (2010). The cognitive interview: A metaanalytic review and study space analysis of the past 25 years. Psychology, Public Policy, \& Law, 16, 340-372. doi:10.1037/a0020518

Meyer, P. (2010). Lie spotting: Proven techniques to detect deception. St. Martin's Press, New York.

Miller, W. R., \& Rollnick, S. (2013). Motivational interviewing: Helping people change. New York: Guilford Press. 
Miron, A. M., \& Brehm, J. W. (2006). Reactance theory-40 years later. Zeitschrift für Sozialpsychologie, 37, 9-18. doi:10.1024/0044-3514.37.1.9

Mitchell, J. E., \& Harlow, B. (2016). Enhanced interrogation: Inside the minds and motives of the Islamic terrorists trying to destroy America. New York: Crown Forum.

Moore, T. E., Cutler, B. L., \& Shulman, D. (2014). Shaping eyewitness and alibi testimony with coercive interview practices. The Champion, October, 34-40.

Morgan III, C. A., Doran, A., Steffian, G., Hazlett, G., \& Southwick, S. M. (2006). Stress-induced deficits in working memory and visuo-constructived abilities in special operation soldiers. Biological Psychiatry, 60, 722-729. doi:10.1016/j.biopsych.2006.04.021

Morgan III, C. A., Hazlett, G., Doran, A., Garrett, S., Hoyt, G., Thomas, P., Baranoski, M., \& Southwick, S. M. (2004). Accuracy of eyewitness memory for persons encountered during exposure to highly intense stress. International Journal of Law and Psychiatry, 27, 265-279. doi: 10.1016/j.ijlp.2004.03.004

Morgan, III, C. A., Southwick, S., Steffian, G., Hazlett, G. A., \& Loftus, E. (2013). Misinformation can influence memory for recently experienced, highly stressful events. International Journal of Law and Psychiatry, 36, 11-17, doi:10.1016/j/ijlp.2012.11.002

Morell, M., \& Harlow, B. (2015). The Great War of Our Time: The CIA's Fight Against Terrorism-From al Qa 'ida to ISIS. New York: Hachette Book Group.

Mortimer, A. \& Shepherd, E. (1999). Frames of mind: Schemata guiding cognition and conduct in the interviewing of suspected offenders. In A. Memon and R. 
Bull (Eds), Handbook of Psychology Interviewing (pp. 293-315). Chichester, UK: Wiley.

Moyar, M. (1997). Phoenix and the Birds of Prey: The CIA's Secret Campaign to Destroy the Viet Cong. Annapolis, MD: Naval Institute Press.

Nahari, G., Vrij, A., \& Fisher, R. P. (2012). Does the truth come out in the writing? SCAN as a lie detection tool. Law \& Human Behavior, 36, 68-76. doi:10.1007/s10979-011-9264-6

Nahari, G., Vrij, A., \& Fisher, R. P. (2014a). Exploiting liars' verbal strategies by examining the verifiability of details. Legal and Criminological Psychology, 19, 227-239, doi:10.1111/j.2044-8333.2012.02069.x

Nahari, G., Vrij, A., \& Fisher, R. P. (2014b). The Verifiability Approach: Countermeasures facilitate its ability to discriminate between truths and lies. Applied Cognitive Psychology, 28, 122-128. doi:10.1002/acp.2974

Narchet, F. M., Meissner, C. A., \& Russano, M. B. (2011). Modeling the influence of investigator bias on the elicitation of true and false confessions. Law and Human Behavior, 35, 452-465. doi:10.1007/s10979-010- 9257-х

Narchet, F. M., Russano, M. B., Kleinman, S. M., \& Meissner, C. A. (2016). A (nearly) $360^{\circ}$ perspective of the interrogation process: Communicating with high-value targets. In G. Oxburgh et al. (Eds.), Communication in investigative and legal contexts: Integrated approaches from forensic psychology, linguistics, and law enforcement (pp. 159-178). John Wiley \& Sons.

Nash, R. A., \& Wade, K. A. (2009). Innocent but proven guilty: Using false video evidence to elicit false confessions and create false beliefs. Applied Cognitive Psychology, 23, 624-637. doi:10.1002/acp.1500 
National Research Council (2003). The polygraph and lie detection. Committee to Review the Scientific Evidence on the Polygraph. Washington, DC: The National Academic Press.

Nelson, T. O., Dunlosky, J., White, D. M., Steinberg, J., Townes, B. D., \& Anderson, D. (1990). Cognition and metacognition at extreme altitudes on Mount Everest. Journal of Experimental Psychology: General, 119, 367-374. doi:10.1037/0096-3445.119.4.367

Newman, E. J., \& Garry, M. (2013). False memory. In T. J. Perfect \& D. S. Lindsay Eds.) The SAGE Handbook of Applied Memory (pp. 110-126). New York: Sage Publications.

O'Mara, S. (2009). Torturing the brain. Trends in Cognitive Science, 13, 497-500. doi: 10.1016/j.tics.2009.09.001

O'Mara, S. (2015). Why torture does not work: The neuroscience of interrogation. Cambridge, MA: Harvard University Press.

Oxburgh, G., \& Ost, J. (2011). The use and efficacy of empathy in police interviews with suspects of sexual offences. Journal of Investigative Psychology and Offender Profiling, 8, 178-188. doi:10.1002/jip

Paulo, R., Albuquerque, P. B., \& Bull, R. (2016). The Enhanced Cognitive Interview: Expressions of uncertainty, motivation and its relation with report accuracy. Psychology, Crime and Law, 22, 366-381. doi:10.1080/1068316X.2015.1109089

Payne, D. J., Tucker, M. A., Ellenbogen, J. M., Wamsley, E. J., Walker, M. P., Schacter, D. L., \& Stickgold, R. (2012). Memory for semantically related and unrelated declarative information: The benefit of sleep, the cost of wake. PlosOne, 7, 3, e33079. doi: 10.1371/journal.pone.0033079 
Peer, E., Acquisti, A., \& Shalvi, S. (2014). "I cheated, but only a little": Partial confessions to unethical behavior. Journal of Personality and Social Psychology, 106, 202-217. doi:10.1037/a0035392.202

Perillo, J. T., \& Kassin, S. M. (2011). Inside interrogation: The lie, the bluff, and false confessions. Law and Human Behavior, 35, 327-337. doi:10.1007/s10979-010-9244-2

Peters, E. (1996). Torture. Philadelphia: University of Pennsylvania Press.

Pfiffner, J. P. (2014). The efficacy of Coercive Interrogation. In T. Lightcap \& J. P. Pfiffner (Eds.), Examining Torture (pp. 127-157). Palgrave Macmillan US.

Pierro, A., \& Kruglanski, A. W. (2008). "Seizing and freezing” on a significantperson schema: Need for closure and the transference effect in social judgment. Personality and Social Psychology Bulletin, 34, 1492-1503. doi:10.1177/0146167208322865

Pilcher, J. J., Nadler, E., \& Busch, C. (2002). Effects of hot and cold temperature on performance: A meta-analytic review. Ergonomics, 45, 682-698. doi:10.1080/00140130210158419

Pope, B., Blass, T., Siegman, A. W., \& Raher, J. (1970). Anxiety and depression in speech. Journal of Consulting and Clinical Psychology, 35, 128-133. doi: $10.1037 / \mathrm{h} 0029659$

Porter, S., \& ten Brinke, L. (2008). Reading between the lies: Identifying concealed and falsified emotions in universal facial expressions. Psychological Science, 19, 508-514. doi:10.1111/j.1467-9280.2008.02116.x

Ratcliff, R., \& Van Dongen, H. P. (2009). Sleep deprivation affects multiple distinct cognitive processes. Psychonomic Bulletin \& Review, 16, 742-751. doi:10.2466/02.05.10 
Redlich, A. D., Kelly, C. E., \& Miller, J. C. (2014). The who, what, and why of human intelligence gathering: Self-reported measures of interrogation methods. Applied Cognitive Psychology, 28, 817-828. doi:10.1002/acp.3040

Rejali, D. (2009). Torture and democracy. Princeton University Press.

Rodriguez, J. A. (2012). Hard Measures. NY: Threshold Editions.

Ross, L., Greene, D., \& House, P. (1977). The "false consensus effect": An egocentric bias in social perception and attribution processes. Journal of Experimental Psychology, 13, 279-301. oi.org/10.1016/0022-1031(77)90049-X

Russano, M. B., Meissner, C. A., Narchet, F. M., \& Kassin, S. M. (2005). Investigating true and false confessions within a novel experimental paradigm. Psychological Science, 16, 481-486. doi:10.1111/j.0956-7976.2005.01560.x

Russano, M. B., Narchet, F. M., Kleinman, S. M., \& Meissner, C. A. (2014). Structured interviews of experienced HUMINT interrogators. Applied Cognitive Psychology, 28, 847-859. doi/10.1002/acp.3069

Samwel, H. J., Evers, A. W., Crul, B. J., \& Kraaimaat, F. W. (2006). The role of helplessness, fear of pain, and passive pain-coping in chronic pain patients. The Clinical Journal of Pain, 22, 245-251. doi:/10.1097/01.ajp.0000173019.72365.f5

Schreiber Compo, N., Hyman Gregory, A. R., \& Fisher, R. P. (2012). Interviewing behaviors in police investigators: A field study of current U.S. sample. Psychology, Crime and Law, 18, 359-375. doi:10.1080/1068316X.2010.494604

Seligman, M.E.P. (1975). Helplessness: On depression, development, and death. San Francisco: W.H. Freeman. 
Shaw, J., \& Porter, S. (2015). Constructing rich false memories of committing crime. Psychological Science, 26, 291-301. doi:10.1177/0956797614562862

Soufan, A. H. (2011). The Black Banners: The Inside Story of 9/11 and the War Against al-Qaeda. New York: W. W. Norton \& Company.

Sporer, S. L., \& Schwandt, B. (2006). Paraverbal indicators of deception: A metaanalytic synthesis. Applied Cognitive Psychology, 20, 421-446. doi:10.1002/acp.1190

Sporer, S. L., \& Schwandt, B. (2007). Moderators of nonverbal indicators of deception: A meta-analytic synthesis. Psychology, Public Policy, and Law, 13, 1-34. doi:10.1037/1076-8971.13.1.1

Stawski, R. S., Sliwinski, M. J., \& Smyth, J. M. (2009). The effects of an acute psychosocial stressor on episodic memory. European Journal of Cognitive Psychology, 21, 897-918. doi:10.1080/09541440802333042

Stockdale, J. B. (2001) Courage under fire. In Department of Philosophy and Fine Arts, United States Military Academy (Eds.), Moral dimensions of the military profession (5th edn.). (pp. 321-334).

Strömwall, L. A., Granhag, P. A., \& Hartwig, M. (2004). Practitioners' beliefs about deception. In P. A. Granhag \& L. A. Strömwall (Eds.), Deception detection in forensic contexts (pp. 229-250). Cambridge, England: Cambridge University Press.

Sullivan, M. J. L., Thorn, B., Haythornthwaite, J. A., Keefe, F., Martin, M., Bradley, L. A., et al. (2001). Theoretical perspectives on the relation between catastrophizing and pain. Clinical Journal of Pain, 17, 52-64. doi: 10.1097/00002508-200103000- 00008 
Tarrant, M., Branscombe, N. R., Warner, R. H., \& Weston, D. (2012). Social identity and perceptions of torture: It's moral when we do it. Journal of Experimental Social Psychology, 48, 513-518. doi:10.1348/014466608X373589

Tekin, S., Granhag, P. A., Strömwall, L., Giolla, E. M., Vrij, A., \& Hartwig, M. (2015). Interviewing strategically to elicit admissions from guilty suspects. Law and Human Behavior, 39, 242-252. doi:10.1037/lhb0000131

The Guardian, November 23 (2015). Donald Trump on waterboarding: 'Even if it doesn't work they deserve it' https://www.theguardian.com/usnews/2015/nov/24/donald-trump-on-waterboarding-even-if-it-doesnt-workthey-deserve-it

Tulving, E., \& Thomson, D. M. (1973). Encoding specificity and retrieval processes in episodic memory. Psychological Review, 80, 352-373. doi:10.1037/h0020071

United Nations report (2016) (available at http://antitorture.org/wpcontent/uploads/2016/09/Report_A-71-298_English.pdf)

Valentine, T., \& Mesout, J. (2009). Eyewitness identification under stress in the London Dungeon. Applied Cognitive Psychology, 23, 151-161. doi: 10.1002/acp.1463

Vallano, J. P., Evans, J. R., Schreiber Compo, N., \& Kieckhaefer, J. M. (2015). Rapport- Building during witness and suspect interviews: A Survey of Law Enforcement. Applied Cognitive Psychology, 29, 369-380. doi:10.1002/acp.3115 
Vallano, J. P., \& Schreiber Compo, N. (2015). Rapport-building with cooperative witnesses and criminal suspects: A theoretical and empirical review. Psychology, Public Policy, and Law, 21, 85-99. doi:10.1037/law0000035

Van Bergen, S., Jelicic, M., \& Merckelbach, H. (2008). Interrogation techniques and memory distrust. Psychology, Crime \& Law, 14, 425-434. doi:10.1080/10683160701822533

Van Hiel, A., \& Mervielde, I. (2002). Effects of ambiguity and need for closure on the acquisition of information. Social Cognition, 20, 380-408. doi:10.1521/ soco.20.5.380.21124

Vredeveldt, A., Hitch, G. J., \& Baddeley, A. D. (2011). Eye-closure helps memory by reducing cognitive load and enhancing visualisation. Memory \& Cognition, 39, 1253-1263. doi:10.3758/s13421-011-0098-8

Vredeveldt, A., van Koppen, P. J., Granhag, P. A. (2014). The inconsistent suspect: A systematic review of different types of consistency in truth tellers and liars. In R. Bull (Ed.), Investigative Interviewing (pp. 183-207). New York: Springer Science+Business Media DOI 10.1007/978-1-4614-9642-7_10

Vrij, A. (1994). The impact of information and setting on detection of deception by police detectives. Journal of Nonverbal Behavior, 18, 117-137. doi:10.1007/BF02170074

Vrij, A. (1995). Behavioral correlates of deception in a simulated police interview. Journal of Psychology: Interdisciplinary and Applied, 129, 15-29. doi:10.1080/00223980.1995.9914944

Vrij, A. (2005). Criteria-Based Content Analysis: A qualitative review of the first 37 studies. Psychology, Public Policy, and Law, 11, 3-41. doi:10.1037/10768971.11.1.3 
Vrij, A. (2006). Challenging interviewees during interviews: The potential effects on lie detection. Psychology, Crime, \& Law, 12, 193-206. doi:10.1080/10683160512331331319

Vrij, A. (2008). Detecting lies and deceit: Pitfalls and opportunities, second edition. Chichester: John Wiley and Sons.

Vrij, A. (2014). Myths and opportunities in verbal and nonverbal lie detection. In M. St Yves (Ed.), Investigative interviewing: The essential (pp. 226-239). Toronto, Canada: Thomson Reuters.

Vrij, A., Fisher, R., Blank, H. (2015). A cognitive approach to lie detection: A metaanalysis. Legal and Criminological Psychology. doi:10.1111/lcrp.12088

Vrij, A., Fisher, R., Blank, H., Leal, S., \& Mann, S., (2016). A cognitive approach to elicit nonverbal ane verbal cues of deceit. In J. W. van Prooijen \& P. A. M. van Lange (Eds.), Cheating, corruption, and concealment: The roots of dishonest behavior (pp. 284-310). Cambridge, England: Cambridge University Press.

Vrij, A., \& Granhag, P. A. (2012a). Eliciting cues to deception and truth: What matters are the questions asked. Journal of Applied Research in Memory and Cognition, 1, 110-117. doi.org/10.1016/j.jarmac.2012.02

Vrij, A., Granhag, P.A., Mann, S. \& Leal, S. (2011). Outsmarting the liars: Towards a cognitive lie detection approach. Current Directions in Psychological Science, 20, 28-32. doi:10.1177/0963721410391245

Vrij, A., Granhag, P. A., \& Porter, S. B. (2010). Pitfalls and opportunities in nonverbal and verbal lie detection. Psychological Science in the Public Interest, 11, 89-121._doi:10.1177/1529100610390861 
Vrij, A., Hope, L., \& Fisher, R. P. (2014). Eliciting reliable information in investigative interviews. Policy Insights from Behavioral and Brain Sciences, 1, 129-136. doi:10.1177/2372732214548592

Vrij, A., Mann, S., \& Fisher, R. P. (2006). An empirical test of the Behaviour Analysis Interview. Law and Human Behavior, 30, 329-345. doi:10.1007/s10979-006-9014-3

Vrij, A., Mann, S., Leal, S., \& Granhag, P. A. (2010). Getting into the minds of pairs of liars and truth tellers: An examination of their strategies. The Open Criminology Journal, 3, 17-22. doi:10.2174/1874917801003010017

Wade, K. A., Garry, M., \& Pezdek, K. (in press). De-constructing rich false memories of committing crimes: Commentary on Shaw and Porter (2015). Psychological Science.

Wade, K. A., Green, S. L., \& Nash, R. A. (2010). Can fabricated evidence induce false eyewitness testimony? Applied Cognitive Psychology, 24, 899-908. doi: 10.1002/acp. 1777

Wagenaar, W. A. and Groeneweg, J. (1990), The memory of concentration camp survivors. Applied Cognitive Psychology, 4, 77-87. doi:10.1002/acp.2350040202

Walsh, D. W. \& Bull, R. (2010a). Interviewing suspects of fraud: An in-depth analysis of interviewing skills. The Journal of Psychiatry \& Law, 38, 99-135. Doi:10.1177/009318531003800106

Walsh, D. W., \& Bull, R. (2010b). What really is effective in interviews with suspects? A study comparing interviewing skills against interviewing outcomes. Legal and Criminological Psychology, 15, 305-321. doi:10.1348/135532509X463356 
Walsh, D. W., \& Bull, R. (2012). How do interviewers attempt to overcome suspects' denials? Psychiatry, Psychology \& Law, 19, 151-168. doi:10.1080/13218719.2010.543756

Wachi, T., Kuraishi, H., Watanabe, K., Otsuka, Y., Yokota, K., \& Lamb, M. E. (2017). Police officers' ability to detect lies within a deception paradigm. Psychology, Public Policy, and Law. doi.org/10.1037/law0000124

Webster, D. M. (1993). Motivated augmentation and reduction of the overattribution bias. Journal of Personality and Social Psychology, 65, 261-271. doi:10.1037/0022-3514.65.2.261

Webster, D. M., \& Kruglanski, A. W. (1994). Individual differences in need for cognitive closure. Journal of Personality and Social Psychology, 67, 10491062. doi.org/10.1037/0022-3514.67.6.1049

Webster, D. M., Richter, L., \& Kruglanski, A. W. (1996). On leaping to conclusions when feeling tired: Mental fatigue effects on impressional primacy. Journal of Experimental Social Psychology, 32, 181-195. doi:10.1006/jesp.1996.0009

Wolf, M., \& McElvoy, A. (1997). Man Without a Face: The Autobiography of Communism's Greatest Spymaster. New York: Crown.

Wortman, C.B., \& Brehm, J.W. (1975). Responses to uncontrollable outcomes: an integration of reactance theory and the learned helplessness model. In L. Berkowitz (Ed.), Advances in experimental social psychology (Vol. 8, pp. 277-336). New York: Academic Press

Wright, D. S., Nash, R. A., \& Wade, K. A. (2015). Encouraging eyewitnesses to falsely corroborate allegations: Effects of rapport-building and incriminating evidence. Psychology, Crime \& Law, 21, 648-660. doi:10.1080/1068316X. 2015.102854 
Zimmerman, L. A., Veinott, E. S., Meissner, C. M., Fallon, C., \& Mueller, S. T. (2010). Field Training and Testing of Interview and Elicitation Methods (Final Report prepared under Contract W91CRB-09-C-0082 for US ARMY REDCOM Acquisition Center, Aberdeen Proving Ground, MD). Fairborn, OH: Klein Associates Division of Applied Research Associates.

1 We will not discuss lie detection using equipment such as polygraph machines, EEG equipment or brain scanners, as the use of equipment is possible only in a limited number of intelligence interview settings.

${ }^{2}$ For more on the perception of torture as "just deserts" see Liberman (2014); for more nuanced data suggesting that the acceptability of torture may also depend on social identity factors such as whether the interviewee is an ingroup or outgroup member, see Fischer, Oswald, and Seiler (2013, and Tarrant, Branscombe, Warner, and Weston (2012). 